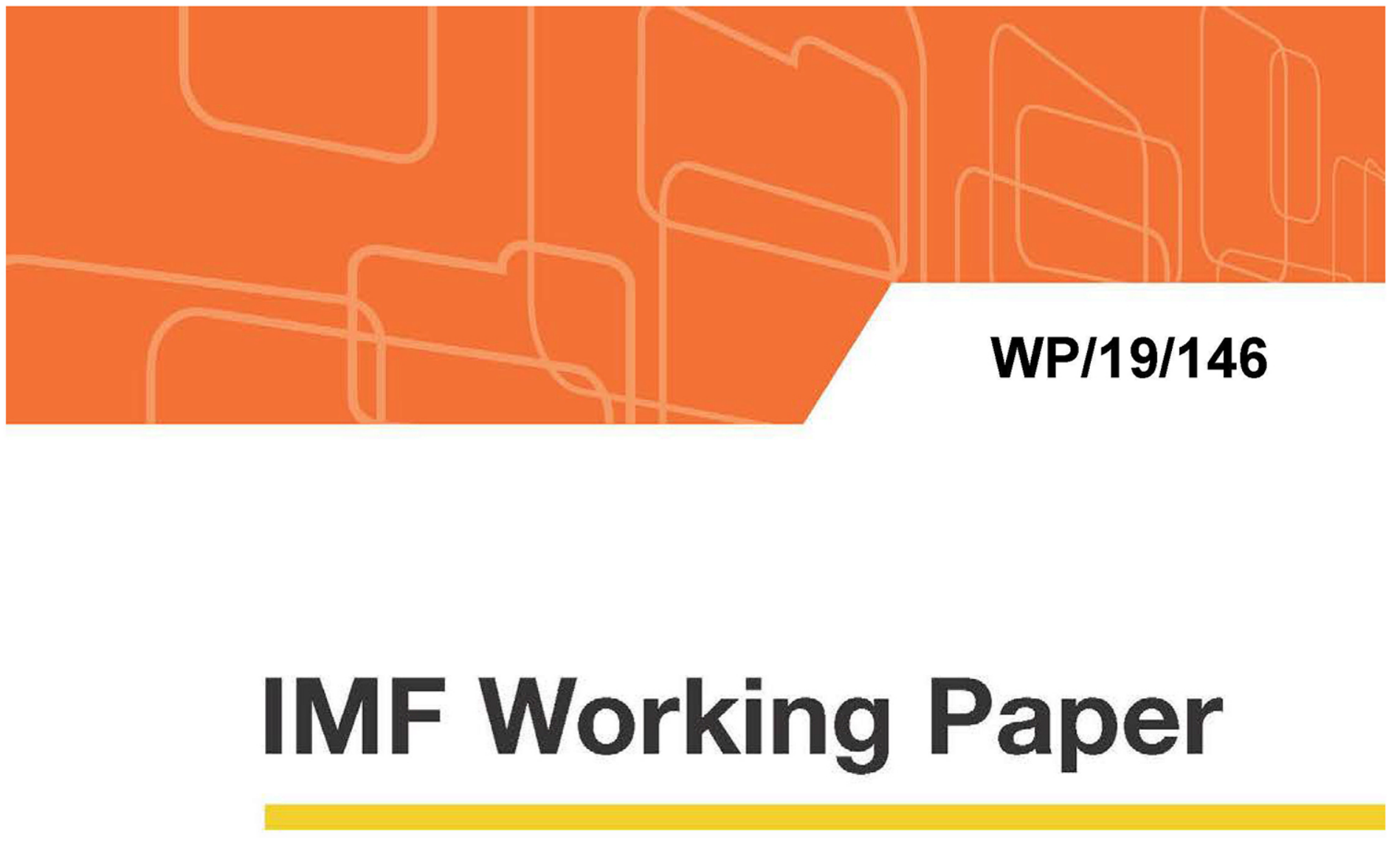

\title{
Drivers of Cross-Border Banking in Sub-Saharan Africa
}

by Paul Mathieu, Marco Pani, Shiyuan Chen, and Rodolfo Maino

IMF Working Papers describe research in progress by the author(s) and are published to elicit comments and to encourage debate. The views expressed in IMF Working Papers are those of the author(s) and do not necessarily represent the views of the IMF, its Executive Board, or IMF management. 


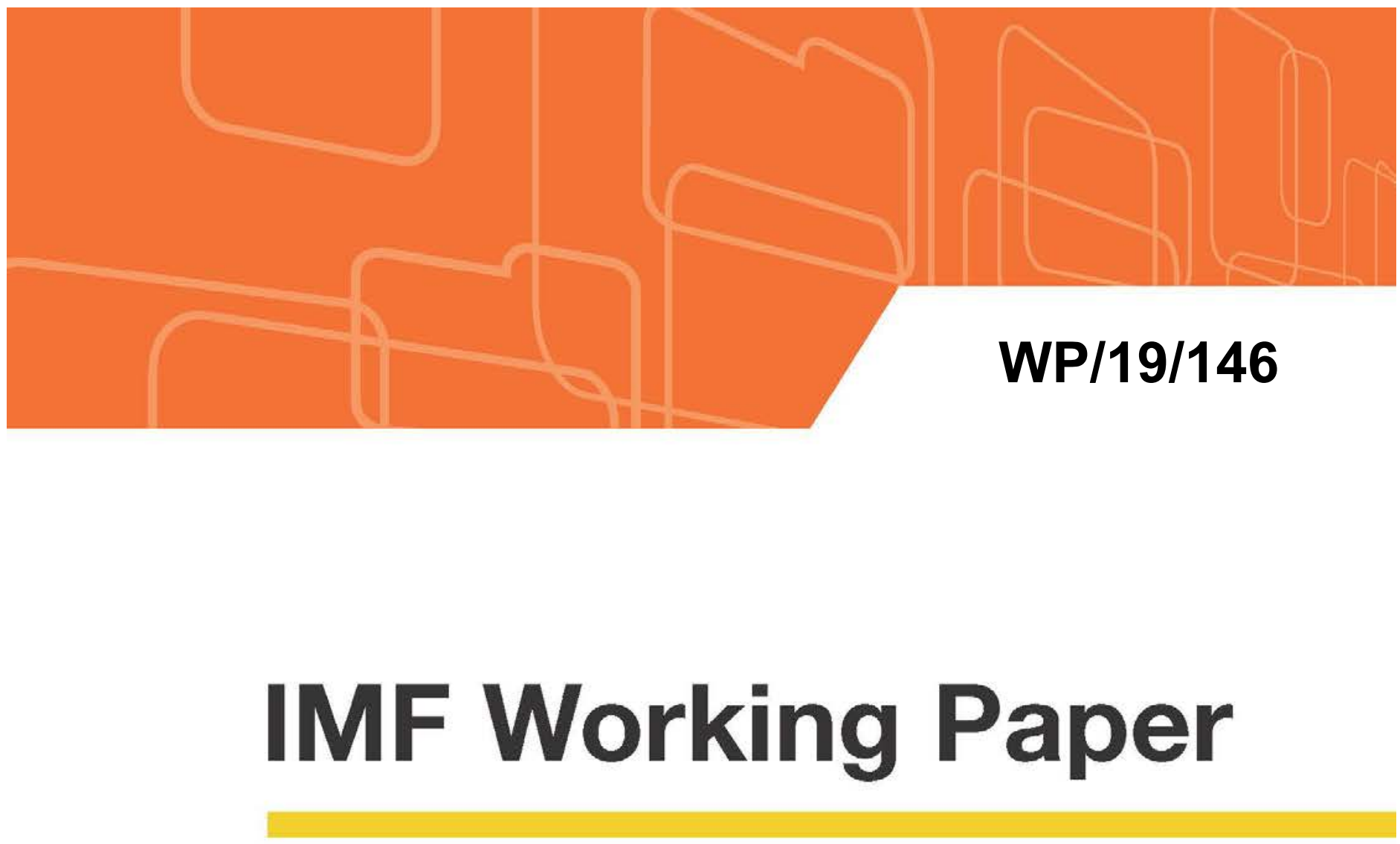

\section{Drivers of Cross-Border Banking in Sub-Saharan Africa}

by Paul Mathieu, Marco Pani, Shiyuan Chen, and Rodolfo Maino

IMF Working Papers describe research in progress by the author(s) and are published to elicit comments and to encourage debate. The views expressed in IMF Working Papers are those of the author(s) and do not necessarily represent the views of the IMF, its Executive Board, or IMF management.

I N T E R N A T I O N A L M O N E T A R Y F U N D 


\title{
IMF Working Paper
}

African and Monetary and Capital Markets Departments

Drivers of Cross-Border Banking in Sub-Saharan Africa

\section{Prepared by Paul Mathieu, Marco Pani, Shiyuan Chen, and Rodolfo Maino ${ }^{1}$}

Authorized for distribution by Ananthakrishnan Prasad

July 2019

\begin{abstract}
IMF Working Papers describe research in progress by the author(s) and are published to elicit comments and to encourage debate. The views expressed in IMF Working Papers are those of the author(s) and do not necessarily represent the views of the IMF, its Executive Board, or IMF management.
\end{abstract}

\begin{abstract}
Using data collected from pan-African banks' (PABs), balance sheets and other sources (Orbis, Fitch), this study identifies some key patterns of cross-border investment in bank subsidiaries by key banking groups in sub-Saharan Africa (SSA) and discusses some of the determinants of this investment. Using a gravity model relating the annual value of a banking group's investment in the net equity of its subsidiaries to a set of explanatory variables, the analysis finds that cross-border banking is in part driven by a search for yield, diversification, and expansion for strategic reasons.

JEL Classification Numbers: F32, F33, F34

Keywords: Cross-border banking flows, Bank leverage, Global banks

Author's E-Mail Address: pmathieu@imf.org; mpani@imf.org; Schen3@imf.org and rmaino@imf.org

\footnotetext{
${ }^{1}$ The authors are very grateful to Torsten Wezel and Anne-Marie Gulde-Wolf for their comments and would also like to thank seminar participants at the IMF for very useful suggestions. This paper benefited from comments and suggestions from Amadou Sy, Nombulelo Braiton, Yizhi Xu, Claudio Raddatz, Filiz Unsal, Hendre Garbers, Chris Papageorgiou, and Francis Vitek. We are also grateful to Ryan Davis, Yun Liu, Benjamin Huston, and Angelin Oey for excellent research assistance and to Christine Luttmer for editorial assistance to finalize this report. All remaining errors are ours.
} 


\section{INTRODUCTION}

Financial integration in Africa has been growing strongly in recent years. In particular, cross-border banking has been developing at a rapid pace. New entrants with their headquarters in Africa are reshaping the landscape in the wake of the exit of traditional European and American banking groups. These developments have potentially important implications for sub-Saharan Africa's growing financial sector and, ultimately, its economy.

As highlighted in a recent IMF paper (Enoch et al., 2015), the number of pan-African banks (PABs) has increased significantly in recent years, and seven groups from the region now dominate the landscape. Banks based in South Africa, Morocco, Nigeria, and the West African Economic and Monetary Union (WAEMU), have emerged. Ecobank (Togo and WAEMU) has the most widespread presence, with operations in 33 SSA countries, while Standard Bank (South Africa) is the largest group by asset size. Three Moroccan banks (Attijariwafa, BMCE/Bank of Africa, and GBCP) have emerged with a large footprint especially in francophone west and central Africa. In addition, about 50 percent of the subsidiaries of Attijariwafa, BMCE/Bank of Africa, Ecobank, and Standard Bank are systemically important in their home countries.

Despite the importance of these developments for the economy of the region, to date the determinants and impact of their growth and the impact they may have on the regional financial sector development have not yet been explored in depth.

This paper aims to address this gap by documenting and analyzing the pattern of growth of pan-African banking, collecting new quantitative evidence, and exploring the drivers of these changes. We update the map of cross-border lending in SSA countries by assessing recent changes and by estimating annual cross-border flows in the eight major SSA cross-border banking groups with the aim of identifying the main drivers of these flows. To this purpose, we apply a gravity model to data collected from PABs balance sheets and other sources, in order to explore, econometrically, the patterns and determinants of cross-border investment in bank subsidiaries in SSA This analysis aims at identifying to what extent cross-border banking is affected by country-specific trends and idiosyncratic factors. More specifically:

- What do the data tell us about the objectives of the cross-border expansion of SSA banking groups? Were they searching for yield, trying to diversify their portfolio, or seeking to obtain a strategic presence in the host country?

- What factors explain the observed differences in cross-border banking presence?

- $\quad$ Are there significant differences between various banking groups?

Several studies have attempted to identify the drivers of cross-border banking flows, focusing mainly on direct cross-border lending and on cyclical aspects, such as the change in behavior during or after a crisis. From a theoretical perspective, Bruno and Shin (2013) have 
highlighted how the cross-border capital flows of banks are driven by the leverage cycle of global banks, providing empirical evidence that these global factors dominate other local factors. Most studies have taken instead an empirical perspective, tracing a country's financial integration to macroeconomic characteristics such as trade openness, the level of financial development, and per capita income (Lane and Milesi-Ferretti, 2008), or documenting banks' international portfolios and cross-border lending respond - at least in the long term - to economic conditions in the originating and recipient country, such as trade links, a common language, or market size a common language (Blank and Bush, 2010; Cerruti et al., 2015), and by institutional and policy variables such as regulations, capital controls, and macroprudential policies (Houston et al., 2012; Cerruti and Zhou, 2018).

Cross-border investment in subsidiaries within multi-national banking groups has received comparatively less attention. Portes and Rey (2005), on the basis of data for 14 advanced economies, have found that a "gravity model" (that relates cross-border flows to the size of the originating and recipient economy and, negatively, to their geographic distance, used as a proxy for a variety of transaction and information costs) explains a significant share of the variance of bilateral gross equity flows (not only within banking groups). Reinhard and Riddiough (2015) have compared intra- and inter-group bank funding across crisis and noncrisis periods, finding that intragroup funding remains comparatively stable even during periods of crisis.

Most of these studies have focused on advanced economies or, at most, emerging market countries; studies on this topic focusing on developing countries are much less numerous and, to our knowledge, in the sub-Saharan African region this issue remains comparatively unexplored, not least owing to a lack of publicly available data. This study attempts to fill this gap by compiling, from a variety of sources, a database of cross-border investment in bank subsidiary equity shared by eight major pan-African banking groups and analyzing the drivers of this investment against a set of potential explanatory factors.

The rest of the paper is organized as follows. Section II assesses the emergence, expansion, and relative size of the pan-African banking groups in terms of assets, liabilities, and equity, and how the picture has evolved over time, while Section III presents the results of the empirical analysis and Section IV concludes.

\section{BORN IN THE REGION-THE CROSS-BORDER EXPANSION OF SSA BANKS}

\section{A. Born Local, Grown Global: The Emergence of SSA-Based Regional Banking Groups}

Cross-border banking - the presence in a country of branches and subsidiaries of banks whose headquarters are established in another country - is in no way a new phenomenon in sub-Saharan Africa. In the past, most cross-border banking groups in Africa were subsidiaries or branches of banks headquartered in Europe. Indeed, since the continent gained independence from colonial metropolis, most of the banks in the region have been subsidiaries (and, in some cases, branches) of multi-national banking groups centered, mainly, in Europe (especially, Britain and France) and in the United States. 
The landscape has changed significantly in recent years, with the retrenchment of European groups and the arrival of new banking groups from other regions, such as North Africa (Morocco), the Middle East (Qatar), and Asia (China and India). This phenomenon accelerated following the global financial crisis. At the same time, banks located in the region have started expanding across borders, leading to the emergence of regional banking groups. Although few of these groups have a presence in most countries in the region, they are commonly referred to as "pan-African groups." Typically, bank holding companies are headquartered in one country and maintain subsidiaries across the region, which are operating under the hosts' rules and regulations. As explored earlier (Enoch et al., 2015), this sets a significant burden on supervisors - who have primary oversight of the holding companies - but open a necessary window of cooperation for host and home country supervisors to exchange information and cooperate.

After sustained and robust growth took off in sub-Saharan around the year 2000, pan-African banking groups expanded rapidly across the region, displacing the previously dominant European groups. Indeed, at present, banking in SSA is now dominated by ten major groups from the continent, based in South Africa, the WAEMU, Nigeria, and Kenya, not counting Moroccan banking groups that, while strongly present south of the Sahara, are centered in North Africa. Figure 1 shows that out of the 14 main banking groups present in the region, 10 are based in SSA. Today, pan-African banks have a more significant footprint in Africa than banks from outside the region. ${ }^{2}$

\footnotetext{
2 In November 2016, Britain's Barclays Bank Plc announced that it was pulling out of Africa. Barclays had a presence in Africa since 1925 and, at the time of the announcement, it owned 62 percent of Barclays Africa Group Limited, which controlled banks in ten African nations, including Ghana, Kenya, Tanzania, and Uganda. In addition, Barclays owned Barclays Bank Egypt and Barclays Bank Zimbabwe.
} 
Figure 1. SSA—Major Pan-African Banks

Number of Subsidiaries, 2002-15

(by Country of Origin)

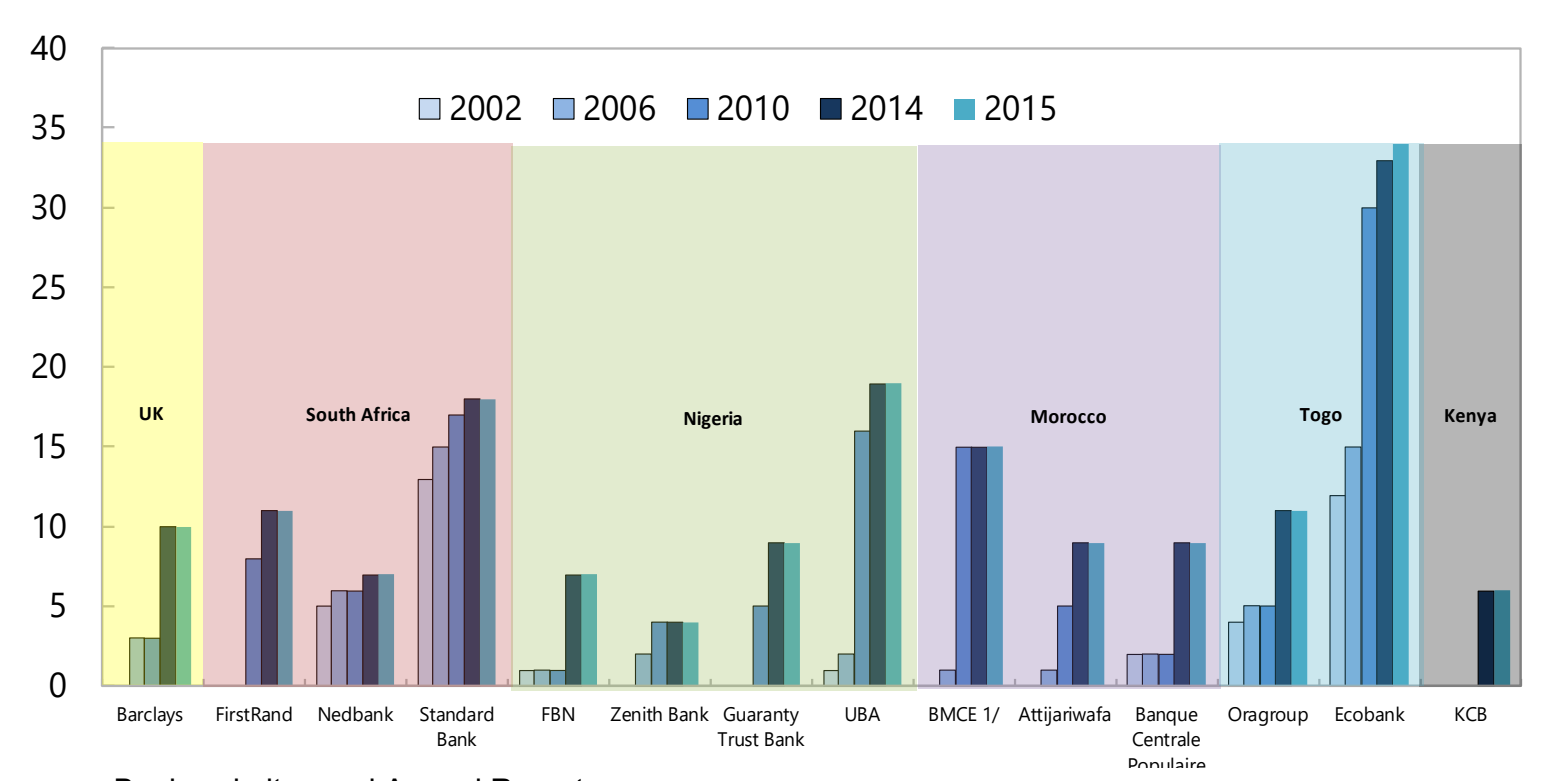

Sources: Bank websites and Annual Reports.

1/ BMCE is a majority owner of Bank of Africa Group since 2010.

This expansion has accelerated in the wake of the global financial crisis (GFC), when European banks retrenched under the pressure of stricter regulations and capital requirements. Between 2006 and 2015 the number of subsidiaries of the 14 largest PABs more than tripled from 53 to 169. Since 2015, however, PABs expansion has stalled (only Ecobank opened one additional subsidiary), due to deteriorating economic conditions in the region.

As noted in an IMF staff study, ${ }^{3}$ PABs have expanded mainly through subsidiaries, via the acquisition of existing banks, including entities divested by retreating European groups. ${ }^{4}$ Greenfield investments are less frequent, but Nigeria's Guarantee Trust Bank has expanded through a combination of acquisitions and greenfield startups, and United Bank for Africa (UBA) has expanded mostly by establishing new entities. The prevalence of subsidiaries over branches partly reflects regulators' wish to minimize contagion.

Most cross-border subsidiaries of the 14 dominant PAB groups are systemically important in their host country, suggesting that the strategic objective of gaining a dominant presence in foreign markets might have been an important motivation of cross border expansion. The bank subsidiaries of these groups are systemic on the liability side (with more than

\footnotetext{
${ }^{3}$ IMF (2015).

${ }^{4}$ Claessens (2016).
} 
10 percent of total deposits) in 31 SSA countries, and, on the asset side (with assets greater or equal to 7 percent of GDP) in 20 SSA countries.

Non-African - mostly European — banking groups continue to have a significant presence in the region even after their retrenchment. On the liability side, the 7 foreign banks with the most widespread presence have systemic operation in 17 SSA countries. On the asset side, they are systemic in nine SSA countries. Only in 8 SSA countries (Comoros, DRC, Eritrea, Ethiopia, Kenya, Sao Tome and Principe, South Sudan, and Zimbabwe) do the 14 selected banks not have operations deemed systemic. In Kenya, however, Kenya Commercial Bankwhich is not included in the seven largest PABs, but has important cross-border operationsis systemic both on the liability and asset side.

With a few exceptions (Cameroon, Madagascar, Mauritius, Mozambique, Seychelles, and Zambia), in most SSA countries PABs have become more important than foreign groups (measured by share of total deposits). The major PABs have a dominant presence particularly in West Africa, where they account for more than 40 percent of deposits in most of the countries.

\section{B. The Cross-Border Expansion of Pan-African Groups}

Between 2000 and 2015, pan-African banking groups invested a total amount of about $\$ 6$ billion (about $\$ 376$ million per year) in cross-border subsidiaries, including syndicated and bilateral loans for infrastructure financing (Figure 2). Most of this investment took place after 2007, when the Standard/Stanbic group acquired full ownership of its Nigerian subsidiary and expanded its share in Kenya. Since 2013, new investment has declined significantly and even turned negative in 2015, when a decline in net equity due to losses was not offset by new injections of capital (Figure 3).

Figure 2. SSA: New Syndicated and Large Bilateral Loans for Infrastructure by Lender Nationality, 2006-15

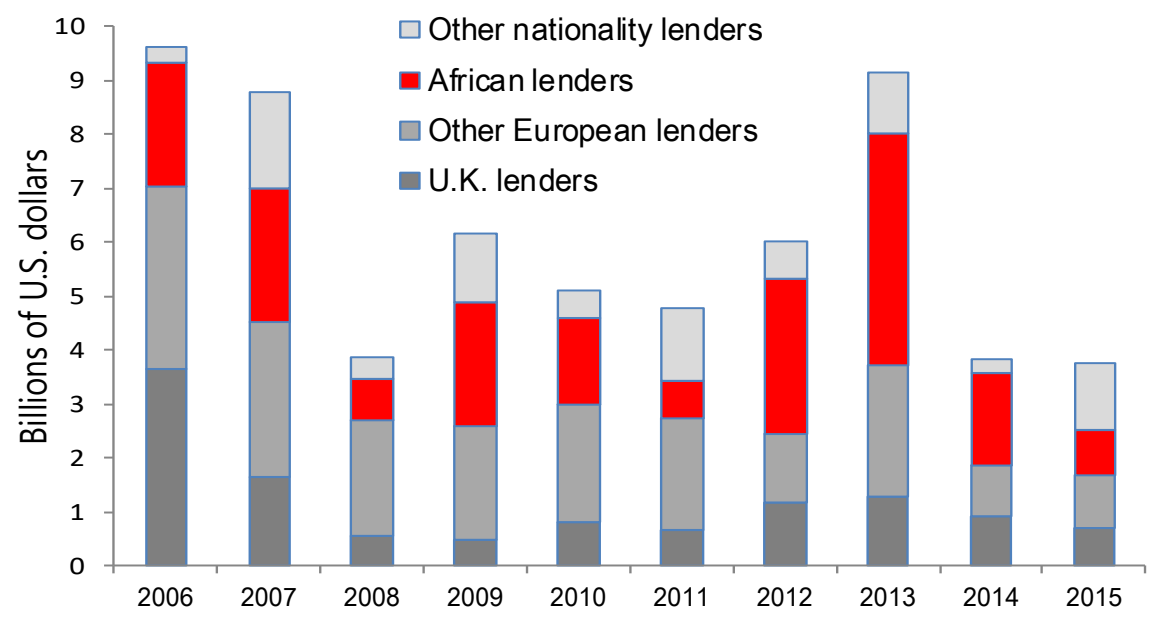

Sources: Dealogic Analytics; and IMF staff calculations. 
Two groups - Ecobank and Standard/Stanbic - account for two-thirds of total investment, with the FirstRand group coming a distant third. Standard/Stanbic and UBA are the largest groups by assets, followed by First Rand and Nedbank. Ecobank is smaller than the others, but it has a constitutional multinational orientation; as a result, it invested more than the others in cross-border subsidiaries (almost one-fourth of its average group's assets during the period, compared with less than 5 percent for the other groups), thereby providing the second largest contribution to cross-border investment (Annex III).

The largest recipient country was Nigeria ( $\$ 1.6$ billion), followed by Kenya ( $\$ 800$ million), Namibia ( $\$ 600$ million), and Ghana ( $\$ 450$ million); in percent of GDP, Namibia, Liberia, and Lesotho received significant investment inflows.

Investment was significantly larger between countries sharing a common language, while a common border does not appear to have encouraged investment significantly. On the surface, indeed, there seems to be no clear relation between investment and the distance between the home and host country. ${ }^{5}$

Groups with higher profitability — as measured by the group's average return on equity (ROE) over the period - appear to have invested less in dollar terms, but not in percent of their assets (Figure 3). Several empirical studies, using cross-country comparisons, found a positive association between foreign bank entry and efficiency and competition (measured by net interest margins, profitability, and cost efficiency). In particular, banks headquartered in the East African Community (or their subsidiaries) have lower spreads and are more efficient than other private domestic banks or subsidiaries of foreign banks headquartered outside of the region. ${ }^{6}$ Enoch et al. (2015) underscored that there is anecdotal evidence that PABs are serving underbanked parts of the population, have led to an increase in branches across the host countries (one example are Nigerian banks in the West African monetary zone), and are exporting innovative business models from their home markets (Moroccan or Kenyan banks).

\footnotetext{
${ }^{5}$ A deeper analysis that takes account of other explanatory factors (Section IV below) shows however that investment does indeed decline with distance.

${ }^{6}$ See World Bank (2013).
} 


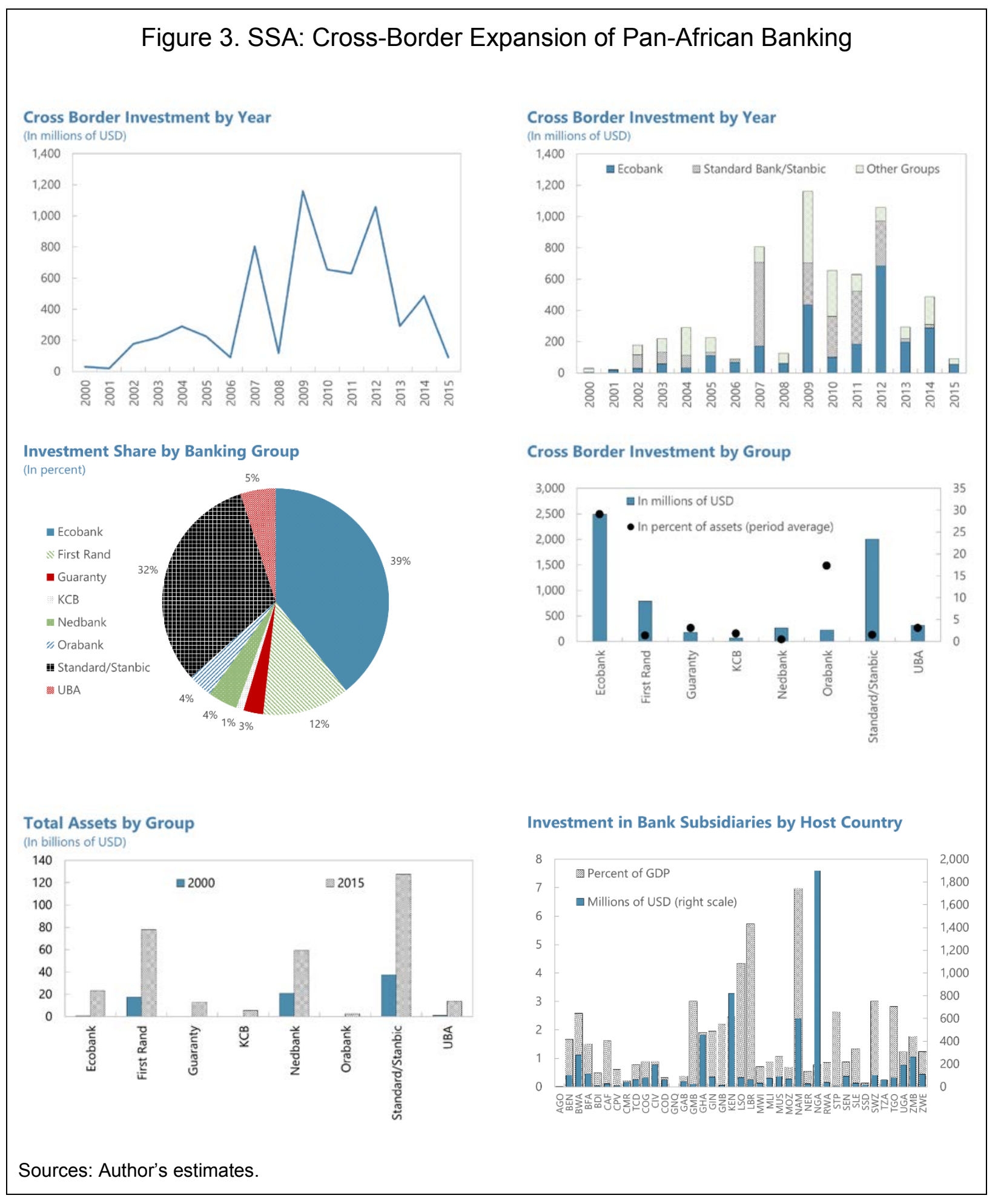




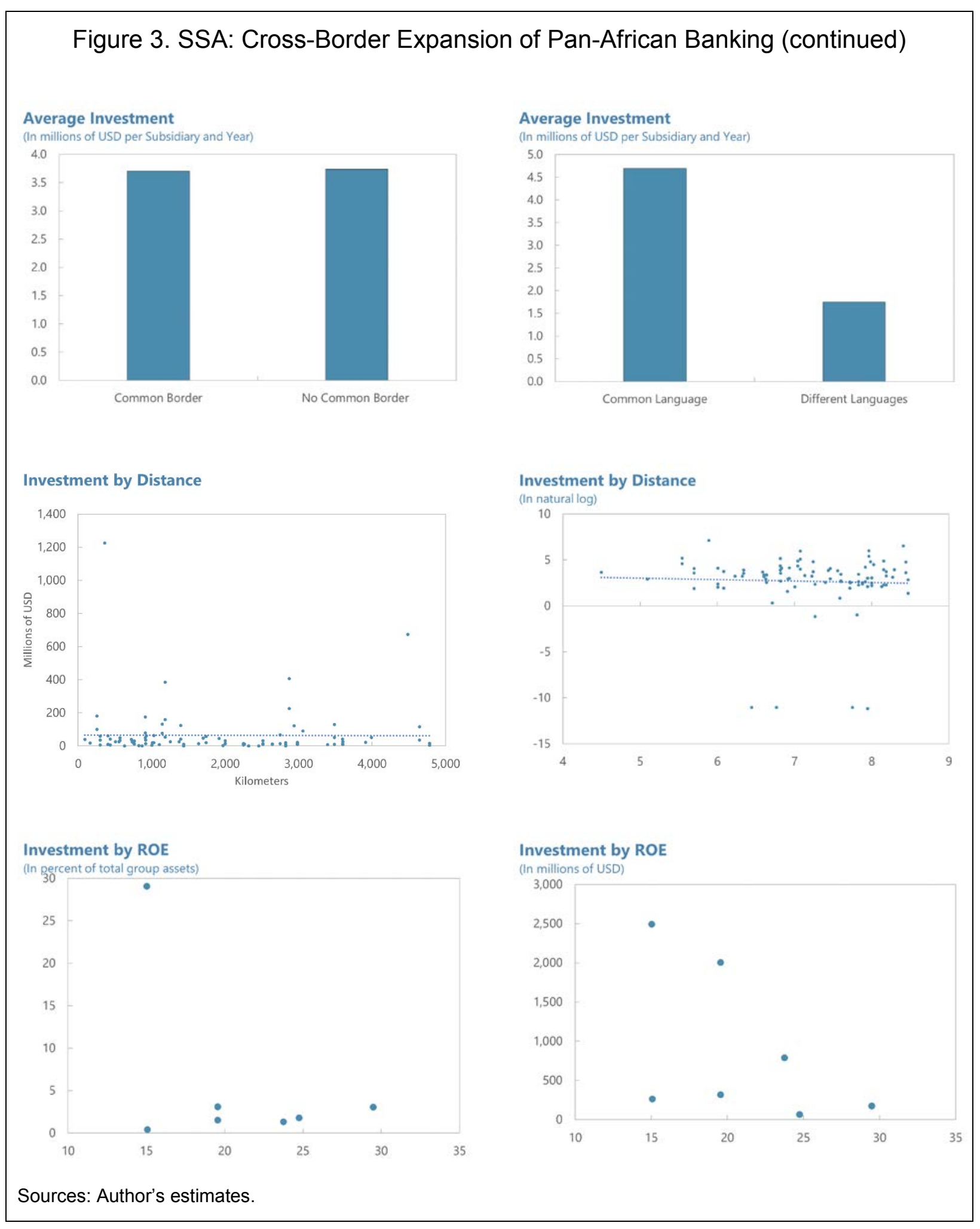

CInternational Monetary Fund. Not for Redistribution 


\section{Network Connectivity}

It is also interesting to compare the network and governance structures of the groups, which can shed light on critical issues such as the risk of cross-border linkages becoming a vehicle of financial contagion: ${ }^{7}$

- $\quad$ The network of ownership linkages among pan-African banks exhibits four major country clusters: South Africa, Nigeria, Morocco, and Kenya (Figure 4).

- Nigerian, Moroccan, and Kenyan banks serve as the central conduits of "controlling" ownership linkages among African countries and sectors. South African and Moroccan banks serve as the origin of most "non-controlling" ownership linkages. ${ }^{8}$

- $\quad$ African banks have significant ownership stakes in a wide variety of non-bank and non-financial entities (Figure 5). This seems to reflect an atypical "universal" banking business model, in which banks have significant direct exposures to industrial and commercial ventures that can potentially give rise to moral hazard and introduce distortions in banks' lending practices. ${ }^{9}$

- $\quad$ From a statistical perspective, the banking sectors of Nigeria, South Africa, Morocco, and Kenya are the main centers of connection among the region's banking sectors. ${ }^{10}$

- A large share of cross-border connectivity in South Africa and Morocco arises from investments outside the region, whereas Nigeria and Kenya's connectivity is driven to a large extent by intra-African ownership linkages.

- Nigerian banks have the largest number of direct controlling ownership linkages, especially in banks (but also in corporations). These linkages are primarily with the banking/corporate sectors of other African economies. By contrast, South African banks are the groups with the largest corporate investments, both inside and outside

\footnotetext{
${ }^{7}$ For a more detailed analysis of pan-African banking networks, including a discussion of potential implications for contagion and supervision, see Enoch et al. (2015).

${ }^{8} \mathrm{~A}$ "controlling ownership linkage" is an equity holding of greater than 50 percent by a parent company in a subsidiary. Controlling ownership linkages require a parent to fully consolidate the activities of a subsidiary into its IFRS-compliant financial reports. A "non-controlling ownership linkage" is an equity holding of less than 50 percent, which does not give a parent effective control over a subsidiary's operations and does not require consolidation for financial reporting purposes.

${ }^{9}$ This can be compared to the late 1800s "German model, with large direct exposures, and intervention, of banks to industry; instead, in late 1900s Japan, banks played an important coordinating role in nonbank conglomerate industrial groups (zaibatsu), but did not have a direct, concentrated capital exposure to their companies.

${ }^{10}$ This is reflected, for instance, in the high values of eigenvector centrality that these countries have in the cross-ownership network. Eigenvector centrality measures the importance of a bank in the ownership network taking account not only of the ownership interests it has in other banks, but also of the ownership interests of its participated banks, and of their participated entities, and so on.
} 
the region; they have comparatively few direct controlling ownership linkages but are heavily connected to the rest of Africa via non-controlling interests.

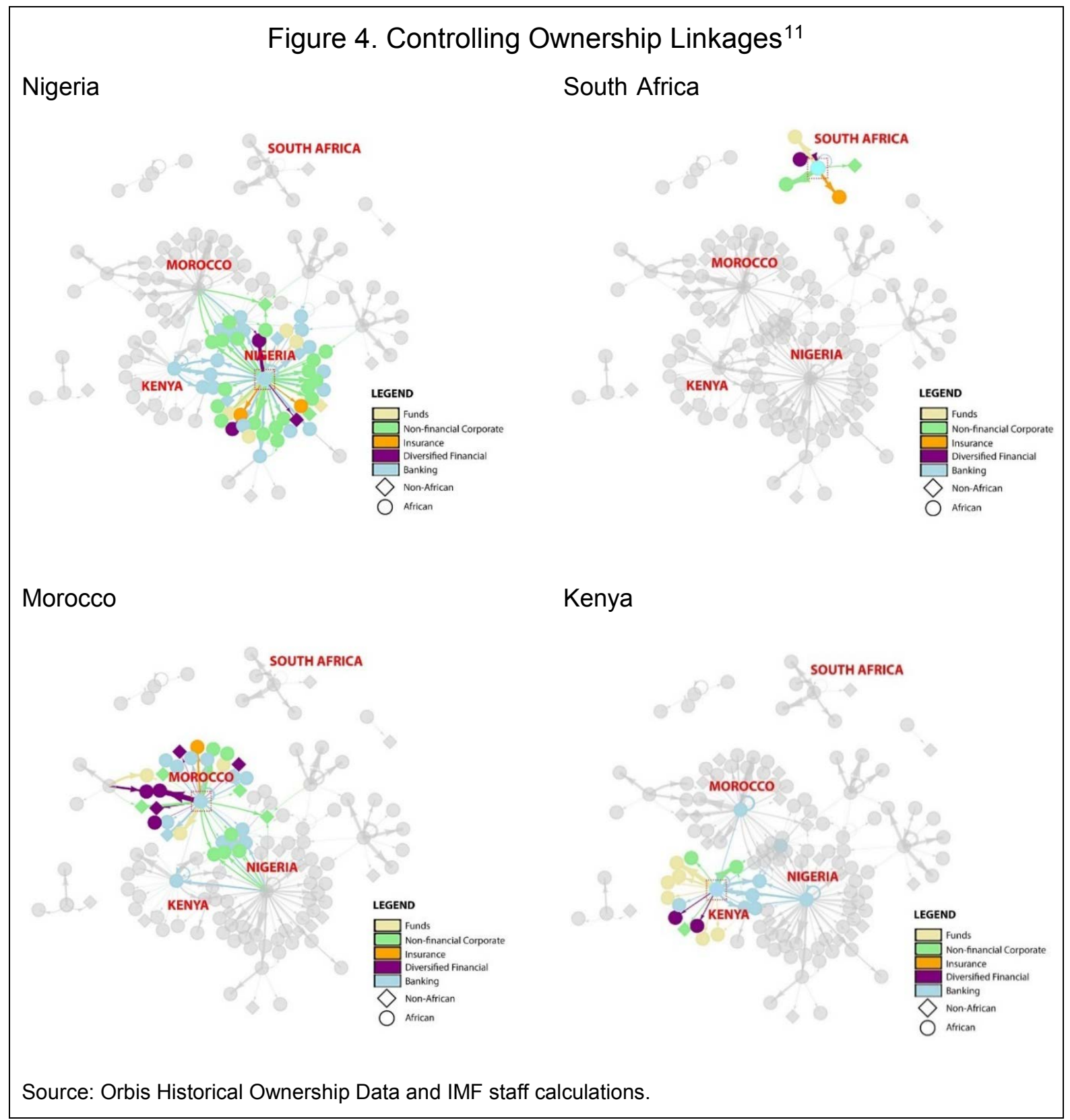

\footnotetext{
${ }^{11}$ Network vertices signify country sectors. Edges signify the weighted frequency of either controlling or noncontrolling parent-subsidiary ownership interests between a given set of country-sector pairs. Weighted frequencies are calculated by cumulatively summing the ownership interests of all entities from "parent country sector A" in "subsidiary country sector B" (e.g., summing the ownership interests of Nigerian banks in Kenyan funds, for example).
} 
Moroccan banks have the second largest number of controlling ownership linkages, evenly split between other African economies and non-African countries. Morocco thus serves as a conduit of African and non-African financial connections. Moroccan banks also have the second largest number of non-controlling ownership linkages (also evenly split between Africa and other regions). Kenyan banks' controlling ownership linkages are primarily with other African banking and asset management sectors.

The ownership interests of Kenyan banks are evenly divided among the corporate, banking, and asset management ("funds") sectors. The country's banks have virtually no ownership of foreign entities outside the region.

In some PABs (notably, the Standard Bank/Stanbic group) the "home" component is dominant: cross-border subsidiaries, while numerous, account for a comparatively small share of the group's assets, which are concentrated in the home country (Figure 6). In these cases, problems in subsidiaries are unlikely to have a significant impact on the home country, and the risk of contagion runs mainly from the home to the host, as shocks in the home country could be transmitted to other countries that host the group's subsidiaries, especially if the latter are locally systemic. In other groups (such as Ecobank), the "network" component is dominant: the home country parent accounts for a comparatively small part of the group's capital and assets, which are spread across a variety of cross-border subsidiaries. This structure poses a much higher risk of contagion, as problems in any part of the group could more easily spread, through the parent, to other countries hosting the group's subsidiaries.

Empirical evidence supports the positive impact of cross-border banking on financial institutions and economies through risk diversification (Arena et al., 2007). However, the effects of contagion depend on the structure of the local subsidiaries as showed by the differences in the impact (by contagion) of the global financial crisis on Eastern Europe and Latin America (Cull and Martinez Peria, 2013).

Another potential channel of contagion arises from two groups' common exposure to the same sector, countries, or subsidiaries (not all necessarily banks). As Figure 4 shows, there are significant common exposures among PAB groups, especially between those based in Nigeria, Kenya, and Morocco (South Africa, in contrast, appears to be comparatively disconnected). ${ }^{12}$

\footnotetext{
${ }^{12}$ Consolidated prudential supervision of the entire group is, thus, critical to ensure adequate capitalization and risk management and reduce the risk that the group becomes a vehicle for the international transmission of shocks. This is a primary concern, considering that in some jurisdictions cross-border collaboration on consolidated supervision is still relatively new and efforts to engage in crisis management preparations are nascent (Enoch et al., 2015).
} 


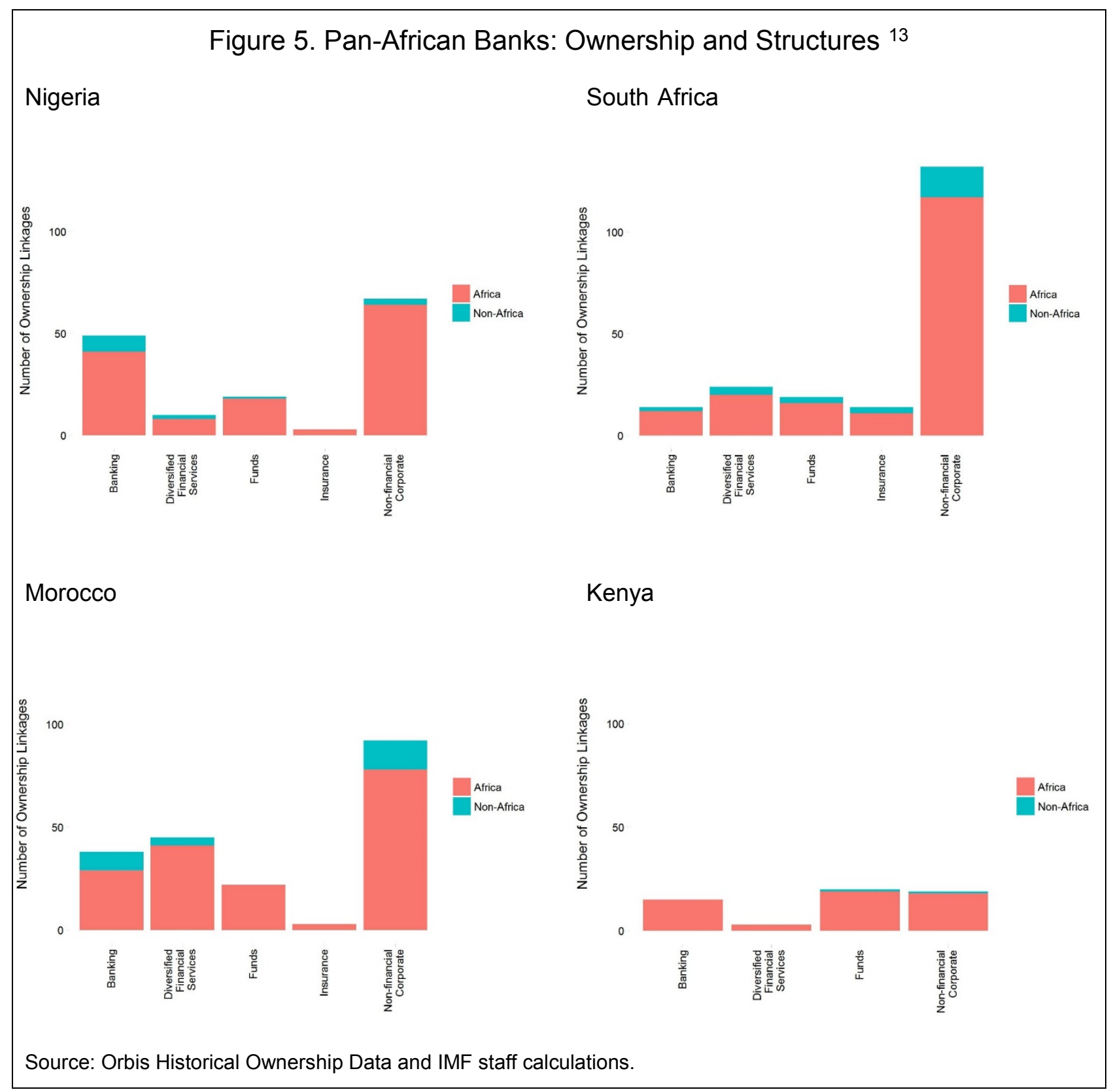

$13 *$ All figures include both controlling and non-controlling ownership linkages. 


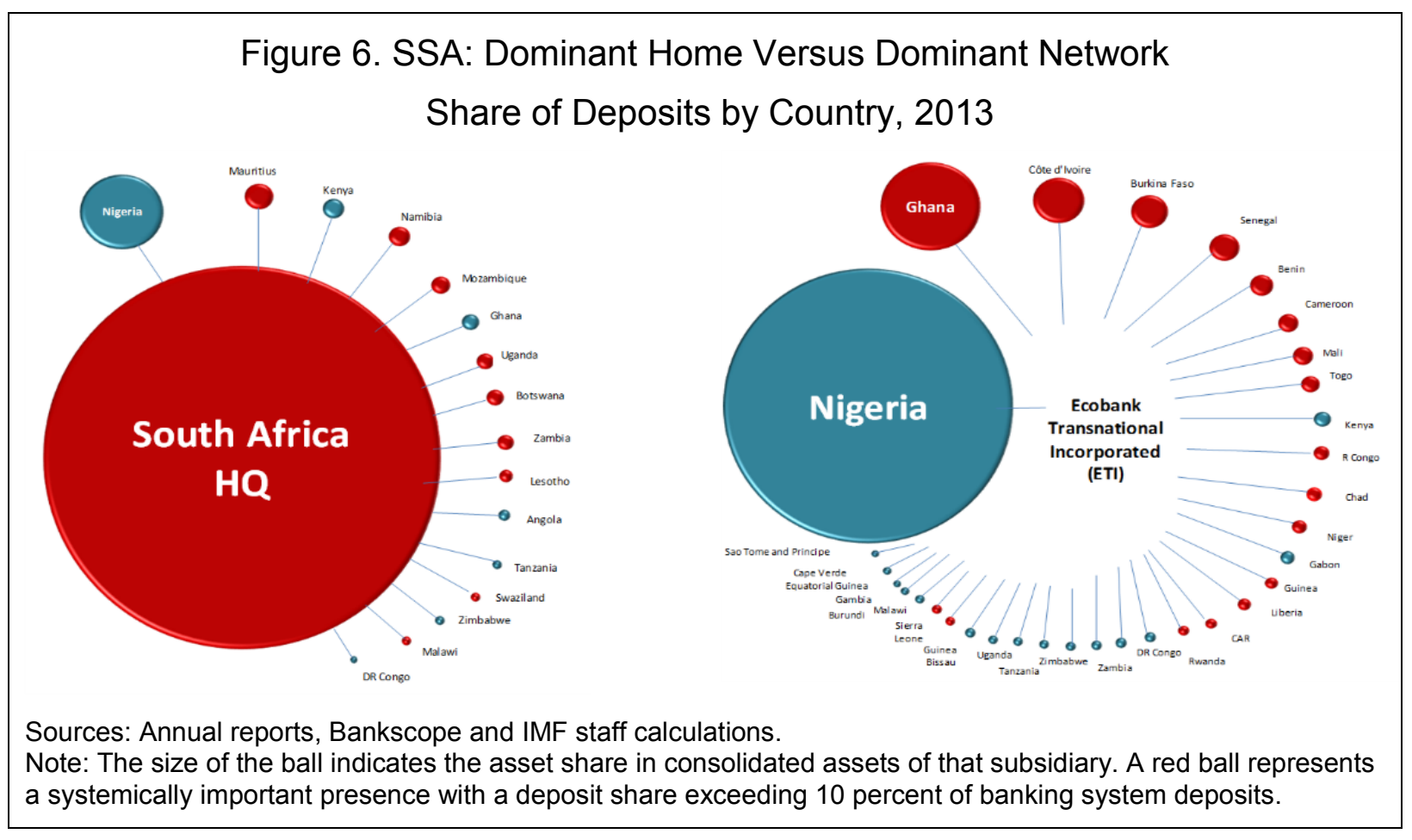




\section{What is Driving The Cross-Border Expansion OF SSA BANKs?}

Why have SSA banking groups expanded so rapidly across borders over the past decade? What has motivated, and oriented, their investment? To address these issues, we have run a panel data regression of each banking group's investment in each cross-border bank subsidiary on a set of explanatory variables that include the size of the home economies, the physical distance between home and host countries, and a set of macroeconomic and group-specific variables. We limited our attention to eight banking groups, all with headquarters in sub-Saharan Africa; this leaves out of the sample not only the European and Middle Eastern banking groups (such as BNP or Qatar National Bank), but also groups with headquarters in Morocco (physically on the African continent but not part of SSA). The period we consider runs over 16 years, from 2000 to 2015; it covers all bank subsidiaries in the SSA region for which data could be collected; and nonbank subsidiaries (such as insurance companies). Banks for which sufficient data were not available are excluded from this study.

While there are several economic (as well as noneconomic and strategic) factors that can explain a banking group's expansion across borders, we focused on a narrow set of variables that include the home and host country's macroeconomic conditions and stability, and the group's financial strength and profitability.

This setting enables us to distinguish between two main potential motives that can inspire a strategy of cross-border expansion: search for yield and diversification.

- $\quad$ Search for yield occurs when the profits than can be obtained by investing in the host country exceed the marginal profits that can be gained by expanding further in the home country (or in other countries where the group is already present). This is the typical marginal equalization process whereby capital flows from its source to the countries where its use is most productive.

- Search for diversification occurs, instead, when a group invests in a different country in order to obtain a flow of potential returns that is weakly (or even negatively) correlated with its existing sources of profits; which improves the return/risk profile of a group's investment. In other words, a group seeking diversification would invest in a new subsidiary, even if the expected returns from this investment are lower than those it could gain by investing more in its existing units, insofar as the returns from this investment vary in accordance with factors that are uncorrelated - or, even better, negatively correlated - with those that drive the returns on the remaining investments of the group. In this case, capital does not necessarily flow to the country where it is most productive but spreads across countries in a way that minimizes the uncertainty of its returns or, rather, achieves a desired balance between risk and return. 


\section{A. Specification of the Model}

The model used to assess the drivers of cross-border bank lending in SSA is based on the classic "gravity" model based on Tinbergen's pioneering study (Tinbergen, 1962). The net investment flow $Y_{G, H, t}$ between two countries $(G$ and $H$ ) at time $t$ is explained as:

$$
Y_{G, H, t}=\alpha_{0}+\alpha_{G, H}+\zeta S_{G, H}+\beta X_{G, t}+\gamma Z_{G, t}+\chi W_{H, t}+\mu \Phi_{G, H}+\varepsilon_{G, H, t}
$$

where,

$\alpha_{0}$ is a constant;

$\alpha_{G, H}$ (in fixed-effects specifications) is a fixed-effect term specific to the group/host country pair $(G, H)$;

$\zeta$ is a vector of coefficients for the gravity component of the model;

$S_{G, H}$ is a $T \times 3$ matrix of three variables representing the gravity component of the model (home country's GDP, host country's GDP and geodesic distance, in kilometers, between the respective capitals); ${ }^{14}$

$\beta$ is a vector of coefficients for the group-specific variables;

$X_{G, t}$ is a matrix of group-specific variables (total equity, assets, return on equity); ${ }^{15}$

$\gamma$ is a vector of coefficients for the home country-specific variables (nominal GDP, distance, language, border);

$Z_{G, t}$ is a matrix of home country-specific variables (real growth, inflation, openness to trade, exchange rate volatility vis-à-vis the U.S. dollar)

$\chi$ is a vector of coefficients for the host country-specific variables;

$W_{H, t}$ is a matrix of host country-specific variables (real GDP growth, inflation, trade openness, exchange rate volatility);

\footnotetext{
${ }^{14}$ This representation closely resembles Newton's "law of gravity" (whence its name), whereby the force of reciprocal attraction between two bodies in space is equal (in logarithms) to the difference between the sum of the masses and the distance between the two bodies.

${ }^{15}$ Subject to data availability, it would be useful to examine alternative specification in which profitability variables (ROE) refer to the group's banking subsidiary in the group's home country rather than to the group as a whole. Such data were not available to the authors.
} 
$\mu$ is a vector of coefficients for the variables $\Phi_{G, H}$ below;

$\Phi_{G, H}$ are "country pair" variables relating to each home/host country pair (common border and common language dummies; bilateral exchange rate volatility). ${ }^{16}$

$\varepsilon_{G, H, t}$ is a (white noise) error term.

The panel data regression includes among the explanatory variables a measure of market size (nominal GDP); indicators of the cost of trading financial asset between the two countries (distance, language, and border dummies); and a set of variables affecting the expected return on asset holdings in both the source (home) and destination (host) country (such as inflation, real GDP growth, the volatility of the nominal exchange rate, and openness to trade).

While there is a wide literature on cross-border banking flows - analyzing, for instance, the behavior of inter-group vis-à-vis intra-group funding in crisis and non-crisis periods (Reinhardt and Riddiough, 2015), or cross-border bank lending through bank as well as non-bank channels (Kerl and Niepmann, 2015) - the specific analysis of the drivers of cross-border banking flows was prompted by the seminal works by Martin and Rey (2004) and Portes and Rey (2006), who applied the "gravity" model—long used to analyze international trade - to the trade in financial services. While Martin and Rey (2004) developed their model to study asset flows, Aviat and Coeurdacier (2007) applied it to asset holdings. Ananchotikul et al., (2015) and Portes and Rey (2005) noted that transactions and holdings of foreign assets are highly correlated and, hence, such distinctions are not particularly relevant (a brief illustration of Martin and Rey's theoretical micro-foundation for the gravity model is provided in Annex II).

\section{B. Data}

The dataset used in this analysis covers 8 pan-African banking groups based in four different countries (South Africa, Nigeria, Kenya, and Togo) and investing in 41 countries in the SSA region, with total consolidated assets ranging from $\$ 2.5$ to $\$ 78$ billion (Figure 7). The dataset includes 1,632 observations for 102 banking subsidiaries over the 16-year period 2000-15.

\footnotetext{
${ }^{16}$ Possible extensions of this model could include among the "country pair" variables a set of variables, changing over time $\left(\Phi_{G, H, t}\right)$, that measure different types of economic interaction between the home and host country that could be variously linked to cross-border investment in banking, such as bilateral trade flows, remittance flows, and cross-border lending (amount of credit provided by a country's banks to the other country's borrowers).
} 


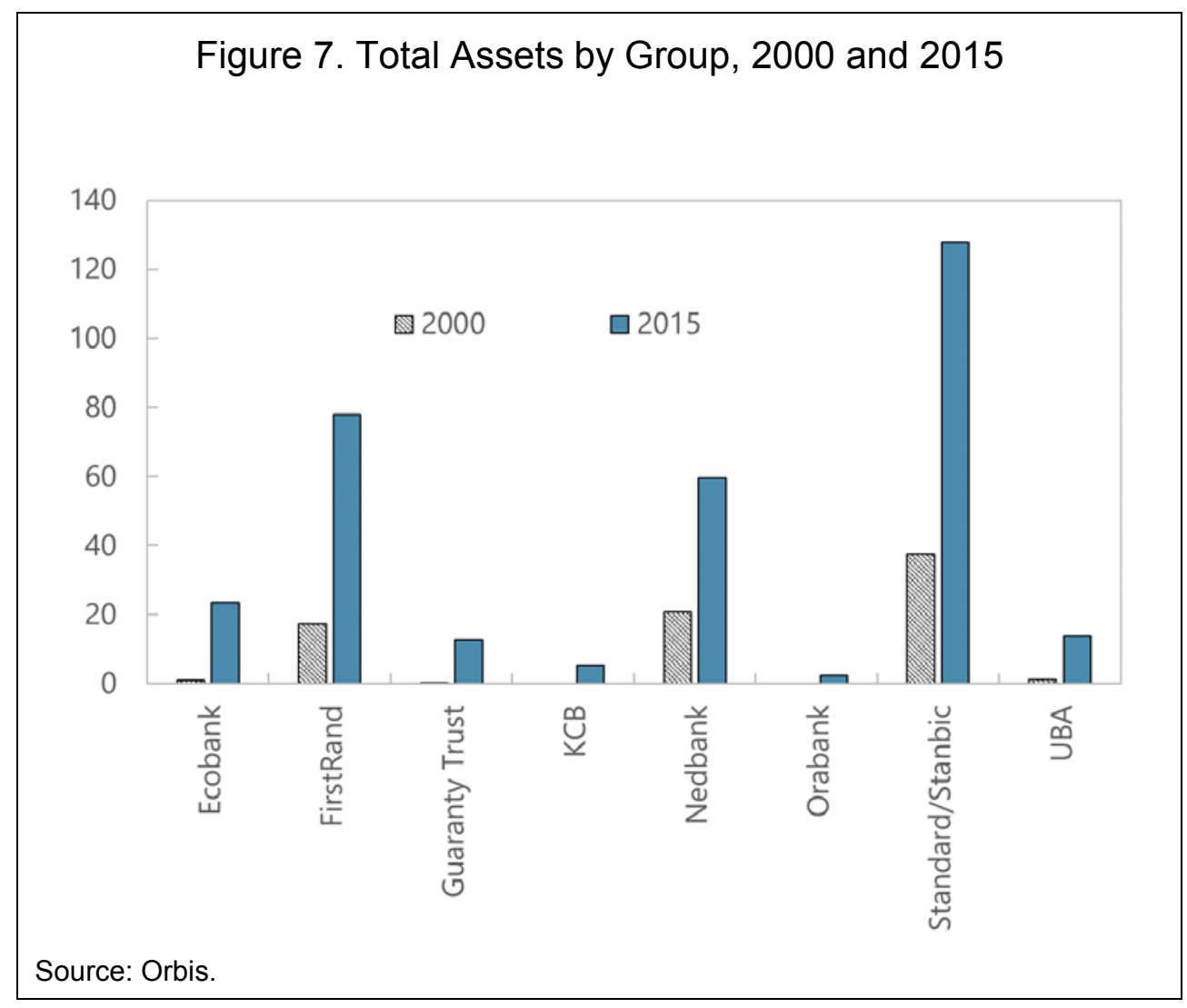

The dependent variable is an estimate of the net investment flows of each of 8 selected bank groups in the equity of their cross-border subsidiaries, by destination country and by year, from 2000 to 2015 (Annex I).$^{17}$ These flows are estimated on the basis of the changes in the net equity of each subsidiary, taking account both of the net purchases (purchases and sales) of equity shares in these entities, and of the group's share of undistributed profits that are reinvested in each subsidiary. ${ }^{18}$

More specifically, the "investment" variable is defined as the sum of: (a) the group's net purchases (gross purchases net of any sales) of ownership shares in a given subsidiary and (b) the group's share in any retained profits of the subsidiary (after-tax profits net of dividends). ${ }^{19}$ All these data are adjusted for any valuation assets due to changes in exchange

\footnotetext{
${ }^{17}$ The groups included are: Ecobank, FirstRand, Guaranty Trust, KCB, Nedbank, the Standard/Stanbic Group, Orabank, and United Bank for Africa (UBA).

${ }^{18}$ Investment in cross-border subsidiaries takes other forms besides participation in equity, such as the provision of subordinated loans or the purchase of securities issued by the subsidiary. Such forms of investment are not considered here owing to a lack of data,

${ }^{19}$ The value of the banking group's ownership in a subsidiary are calculated as the product of its ownership share in the subsidiary by the value of the subsidiary's net equity. The banking group's ownership share in each of its

(continued)
} 
rates. ${ }^{20}$ The data on the net equity of the bank subsidiaries were collected from the Fitch Connect database (in U.S. dollars) and integrated with additional information from published financial statements (in local currency, converted at end-of-period exchange rates).

This model includes four types of explanatory variables: gravity model (and other "country pair") variables, banking group variables, host country macroeconomic variables, and home country macroeconomic variables.

In the gravity model component of the model, the economic mass is proxied by the nominal GDP in U.S. dollars from the World Bank Development Indicators database. The distance is proxied by the distance in kilometers between the financial capital cities, collected from the CEPII GeoDist database or calculated (where missing) using the great circle formula. The model also includes two "country pair" dummy variables aimed at capturing "distance" effects, indicating whether the home and host country share a common language or a common border (based on information provided in the CIA World Factbook).

The banking group variables include total assets, total equity, and ROE, collected from the Fitch Connect database. The host and home country macroeconomic variables include the real GDP growth rate, inflation (percent change in consumption price index), tax revenue in percent of GDP, trade openness (export plus imports in percent of GDP), and the annual average and end-of-period exchange rates (domestic currency per U.S. dollars or bilateral exchange rate between the home and host country, depending on the specification), collected from the World Bank World Development Indicators database and the IMF International Financial Statistics database.

subsidiaries is defined as the ratio of the nominal value of the shares held by all entities controlled by the group to the total nominal value of the shares issued by the subsidiary, irrespective of the value of the group's ownership in the entities that own these shares. These data are collected from the Bureau van Dijk Orbis database, with additional information from the published financial statements.

${ }^{20}$ Changes in the value of the group's ownership share arising from changes in share prices are not considered, as they do not entail any disbursement - or withdrawal - of funds by the group. The group's share of any losses (negative profits) of the subsidiary is also not included. There is, in fact, an asymmetry in the holding group's legal position vis-à-vis the subsidiary's profits and losses: while the group, holding control of the subsidiary, is entitled to receive its full share of profits in the form of dividends if it so decides, in case of losses it has no legal obligation to compensate the subsidiary's losses through a new injection of funds. Hence, while any decision not to distribute (all or part of) the subsidiary's profits as dividends can be considered as a new investment in the subsidiary by the group, losses incurred by the subsidiary and not refunded by the group cannot be considered as a divestment (withdrawal of funds) by the group. 


\section{Methodology}

The model was run in two different ways: (a) by averaging the data by subsidiary over the entire sample period and running the equation on period averages values (a procedure equivalent to the panel data "between" estimation); and (b) by running panel data estimates on the entire dataset. The panel data regressions were run using random effects (RE) and feasible Generalized Least Squares (GLS) estimators, as well as a systemic Generalized Method of Moments estimates (GMM), based on Arellano-Bond and including the lagged dependent variable among the regressors, to take account of the dynamic effects arising from autocorrelation in the dependent variable.

Averaging data by subsidiary over time - a procedure which is essentially equivalent to the panel data "between" estimation, ("BE") — purifies the analysis from the short-term noise that may affect annual data. Investments decisions are generally taken over a multi-year horizon and may not be affected by short-term (high-frequency) fluctuations in the values of some variables from one year to the next. Using the period averages removes this noise and focuses instead on the medium- and long-term determinants of investment; implicitly, it also takes into account the role played by expectations, under the rational expectations assumption that, on average, actual values are a good — if not the best — proxy for previous year's expectations.

In averaged cross-subsidiary ("BE”) format, the basic equation reduces to:

$$
Y_{i, j}=\alpha+\alpha_{i, j}+\zeta S_{i, j}+\beta X_{i}+\gamma Z_{i}+\chi W_{j}+\varepsilon_{i, j}
$$

where $i$ and $j$ identify a banking group and a host country.

Since a sixteen-year period is likely to include structural, as well as cyclical changes, pooled regressions were also run over a shorter and, arguably, more homogeneous period starting in 2006, which coincides with the years that have seen the largest investment flows. ${ }^{21} \mathrm{~A}$ comparison of the results obtained from this shorter period with those yielded by the entire sample period can provide additional information of the changes that have occurred over the last decade and a half.

\footnotetext{
${ }^{21}$ We did not compare the periods preceding and following the global financial crisis (GFC) that started in 2008 because (a) the GFC has had a comparatively mild effect on the region, which was manifested with a lag of about one year; (b) until 2009 investment has been significant only in the four years since 2006, hampering the significance of a comparison between the periods before and after 2009. The GFC, however, was an important indirect contributing factor to the expansion of pan-African banking group, as it spurred a tightening of regulation that induced European banking groups to retreat from the region.
} 
Since different banking groups may follow different investment strategies, the regression was also run separately for each of the two major groups (Ecobank and Standard/Stanbic) and for the other six groups taken together.

Two different measures of annual exchange rate volatility were used, namely: (i) the standard deviation of the monthly bilateral exchange rate vis-à-vis the U.S. dollar, computed every year; and (ii) the standard deviation of the monthly bilateral exchange rate between the home and host country currencies, computed every year. More parsimonious versions of the base equation were also estimated, removing variables whose coefficients are not significantly different from zero and whose comparative lack of data reduces significantly the number of observations available for the estimation.

\section{Results}

Although the econometric analysis conducted here does not consent to identify the direction of causation (which could run both ways or could be driven by common factors), the results suggest that the observed investment flows are consistent with an investment strategy based primarily on transaction cost considerations and, to a lesser extent, on a search for better yields and for opportunities for diversification. The gravity model, which emphasizes demand and supply factors related to the size of the economies and cost factors related to distance - is not rejected by the data. Group profitability and home country growth are associated with lower investment flows, suggesting that groups might have resorted to crossborder investment in order to boost dissatisfactory returns from domestic investments; ${ }^{22}$ and there are indications that bilateral exchange rate volatility may be positively correlated with cross-border investment, suggesting that investment might also have been used as a channel to diversify the groups' asset portfolios.

The "gravity" element, which is well established in the empirical analysis of trade and has been frequently used to analyze cross-banking flows (e.g. Buch, 2005; Herrmann and Mihaljek, 2010; Niepmann, 2015; Gudmundsdottir et al., 2017), is not rejected by the data. This component alone accounts for about 6.6 percent of the variance in the basic specification; ${ }^{23}$ and adding the other explanatory variables brings the "explained" ${ }^{24}$ variance

\footnotetext{
${ }^{22}$ Christensen (2014) suggested that search for yield and linguistic proximity may have been a factor in crossborder banking in SSA by noting that the expansion of SSA banking groups resembled that of Spanish banks in Latin America, which "were on the look-out for new markets [and] had cultural and language advantages" (p. 17).

${ }^{23}$ Random effects on the entire sample.

${ }^{24}$ Any similar words or expressions in the following text should not be interpreted as indicating causality but mere statistical correlation.
} 
to 10.7 percent. ${ }^{25}$ The coefficients of the home and host country GDP are both significantly positive and the coefficient of the distance between the capital cities is significantly negative. ${ }^{26}$ The coefficient for the host economy's size is less than unity, which implies that smaller countries receive proportionately more investment in percent of GDP. There is also evidence that investment flows are stronger between countries sharing a common border or language. A common border appears significant in the panel data regression (especially for Ecobank), while the pooled regressions highlights the favorable impact of a common language, which also appears significant in the panel data for the period from 2006.

A pattern consistent with a "search for yield" strategy is revealed by the significant negative coefficient of the group's ROE (Figure 8), although this correlation appears weaker in some equations in the period after 2006 and is not visible in the Ecobank and Standard/Stanbic groups. $^{27}$

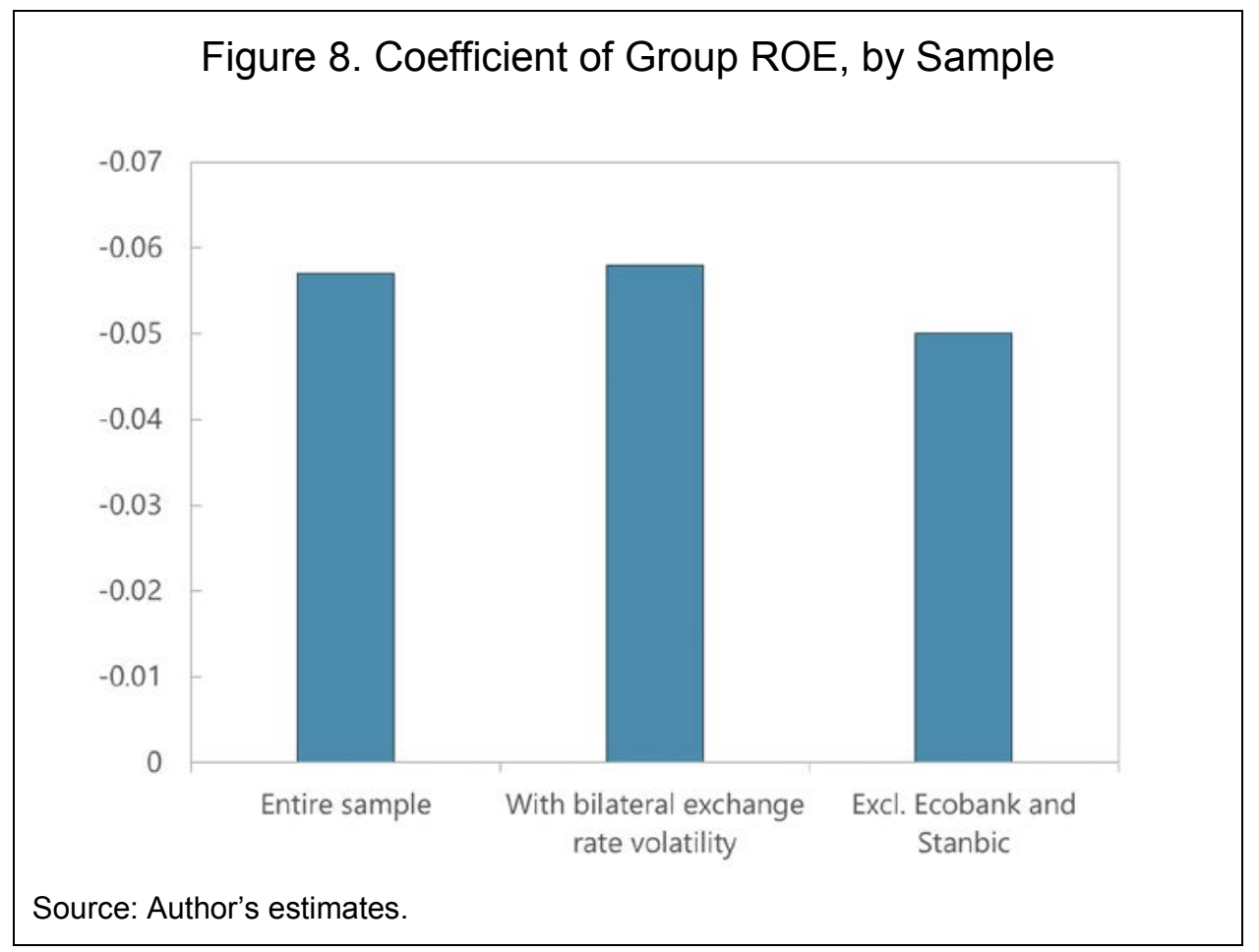

\footnotetext{
${ }^{25}$ For the Standard/Stanbic group, the gravity component explains only 3.5 percent of the variance; when the other explanatory variables are included, the variance rises to 22 percent.

${ }^{26}$ In the cross-subsidiary regression, the home country GDP is not statistically significant, possibly owing to collinearity with other explanatory variables.

${ }^{27}$ This coefficient is not significant for the Ecobank group taken alone and it is significant, but positive, for the Stanbic/Standard group.
} 
Consistent with a search-for-yield motive, there is evidence that could signal some risk avoidance. Inflation in the host country (which could reflect a comparatively unstable macroeconomic environment) appears with a significant negative coefficient in specifications that include the bilateral exchange rate volatility. ${ }^{28}$ The exchange rate volatility against the U.S. dollar also has a significant negative coefficient, especially in the home country, possibly signaling that banking groups are more reluctant to expand across borders when exchange rate risk makes the associated gains more uncertain. Of course, a statistically significant coefficient is not in itself a sufficient proof of a causal link, and these estimates must be interpreted with care.

Signs of a diversification motive are weaker and visible only in the panel data GLS estimates and in the cross-subsidiary regressions run on the period from 2006, where the significant positive coefficient of the volatility of the bilateral exchange rate could manifest a propensity to gain exposure to some volatility that is, presumably, uncorrelated with the factors that drive the profits in the rest of the group. At the same time, the (expected) significant negative coefficient on its squared term could suggests that such exposure is sought only up to a point: when volatility increases beyond a certain point, investment becomes lower.

Group size (measured by equity) appears negatively correlated with cross border investment in the (most active) period after 2006, but this effect may be driven by the Standard/Stanbic group (which may have invested less as its size and capital expanded); except for Ecobank, in the other groups size appears to have a significant positive correlation with investment.

Among home-country variables, only inflation and trade appear with a significant positive coefficient. The coefficient on the inflation variable is significant both in the panel and in the $\mathrm{BE}$ regression (and especially for the Ecobank and Stanbic/Standard groups), but with opposite signs: higher inflation at home is associated with more investment across borders in the short term (Tables 1-4), but with less investment in the long term (Tables 5-7), possibly because a domestic environment of persistently higher inflation rates provides, ceteris paribus, greater profit opportunities for banks. The coefficient on trade openness appears significant, with the predicted positive sign in the panel data regressions, but with an unexpected negative sign in the cross-subsidiary ("BE") regression-possibly a spurious result correlated with the size of the home country, as larger economies tend to be less open, but also have more resources to invest abroad. ${ }^{29}$

For what concerns the economy of the host country, only inflation and growth appear statistically significant, and only in some specifications (not in the cross-subsidiary estimates). Inflation generally has the expected negative sign, but does not appear significant for the Ecobank and Stanbic/Standard groups, which are, instead, sensitive to the inflation

\footnotetext{
28 This variable does not appear to be significant for the sample or for the Ecobank group.

${ }^{29}$ In particular, this result could be biased by Nigeria, home to the Ecobank and Orabank groups.
} 
rate in their home countries; the growth coefficient is significant only in the BE regressions (unsurprisingly, since banking groups may base their investment decisions on the long-term growth prospects of a country, not on its most recent annual values), but with an unexpected negative sign. This result seems to be driven by Ecobank, which apparently pursues a strategy of investing in low-growth countries.

Among the banking groups, empirical support for the search for yield motive appears stronger in the smaller groups than in Ecobank and Standard/Stanbic (Table 4). When these two groups are excluded from the sample, the coefficient on the group's ROE remains negative and strongly significant. Ecobank's annual investment flows are not significantly correlated with the group's profitability but exhibits a significant positively coefficient of the home country inflation rates (which, as noted above, could also be consistent with search for yield) and openness to trade (in other words, Ecobank's cross-border investment has been stronger, ceteris paribus, in periods when inflation in Nigeria and trade flows have been comparatively high). The volatility of the dollar exchange rate, both in the home and in the host country, have a significant negative coefficient. Stanbic/Standard's group ROE has a significant positive coefficient, as would occur if this group cross-border investments were used as a channel to reinvest profits. Interestingly, the group's net equity also exhibits a negative coefficient, even though both net equity and investment increased until 2012 (except for a spike in investment in 2007) and declined thereafter (net equity, marginally; investment, sharply). Standard/Stanbic's investment is also positively correlated with inflation in South Africa (its home country), and with the volatility of the value of the South African rand-but not of the host country currencies, possibly reflecting the large presence of the group in the South African rand's currency area (SADC).

While the volatility of the nominal exchange rate vis-à-vis the U.S. dollar appears with a significant negative coefficient (Table 1), the coefficient of the volatility of the bilateral exchange rate between the home and the host country is not significant (Table 2). While they are both related to the exchange rate, these variables measure different factors: the nominal dollar rate is a measure of the stability of the currency (in the home and in the host country), which can affect bank profits in different directions, increasing risk but also providing more opportunities for gains and arbitrage (for instance, higher volatility could be associated with wider interest rate spreads). The bilateral exchange rate has instead a direct influence on how profits earned in the host country translate into gains measured in home country currency; the higher the volatility of this rate, the higher the risk of investing in the host country. A positive coefficient of this variable might suggest the presence of a diversification motive (groups invest across borders in order to gain more exposure to exchange rate risk), while a negative coefficient is consistent with a search-for-yield motive (higher risk, ceteris paribus, makes the investment less profitable). The fact that the coefficient of this variable is not statistically significant may suggest that the two motives approximately offset each other, but this could also be due to collinearity. 
The variables considered, altogether explain only 10-14 percent of the variance of the dependent variable. The overall $R^{2}$ of the panel data regression ranges from 10 to 14 percent, depending on the specification and the sample. Unsurprisingly, the model explains a larger share of the variance between bank subsidiaries than within each subsidiary over time; which could reflect the fact that investment decisions are likely to respond to fundamental factors with different and variable time lags. When this noise is removed by running the model in the cross-subsidiary ("BE") format, the $R^{2}$ increases remarkably, to about 40 percent. $^{30}$

Among the groups, after controlling for other factors, the Orabank, $\mathrm{KCB}$, and Standard/Stanbic groups appear to invest more cross-border, while Guaranty Trust and UBA invest comparably less (Figure 9).

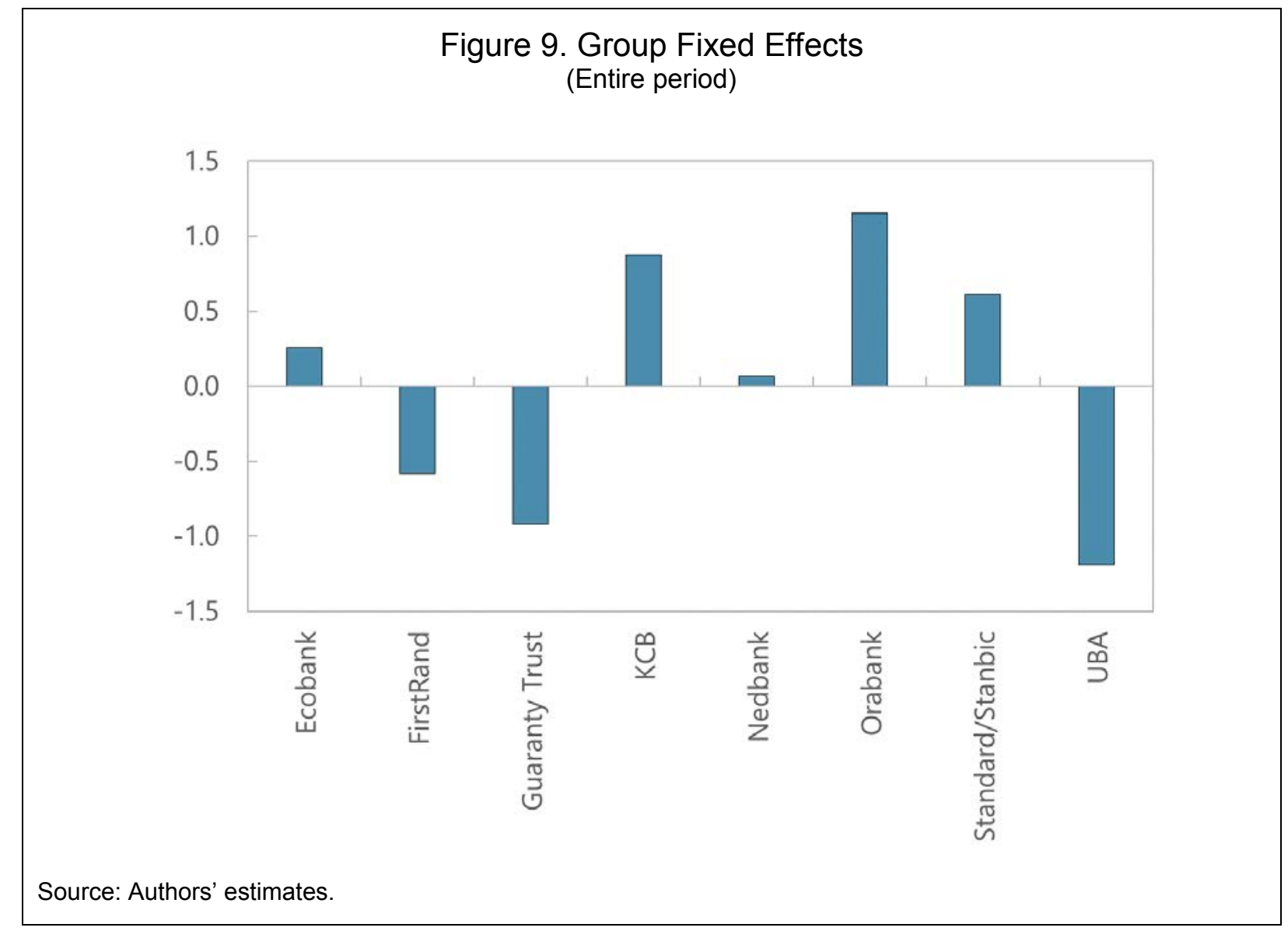

In the same way, after controlling for other factors, Mauritius, Mali, Guinea, and Cote d'Ivoire appear, to receive comparatively more cross-banking investment, while Equatorial Guinea, Angola, and Lesotho appear to receive comparatively less (Figure 10).

\footnotetext{
${ }^{30} \mathrm{~A}$ large share of this increase could however be due to the much lower number of observations (below 100) and may not, in itself signal a higher explanatory power.
} 
Figure 10. Investment in Cross-Border Subsidiaries by Recipient Country (Entire period)

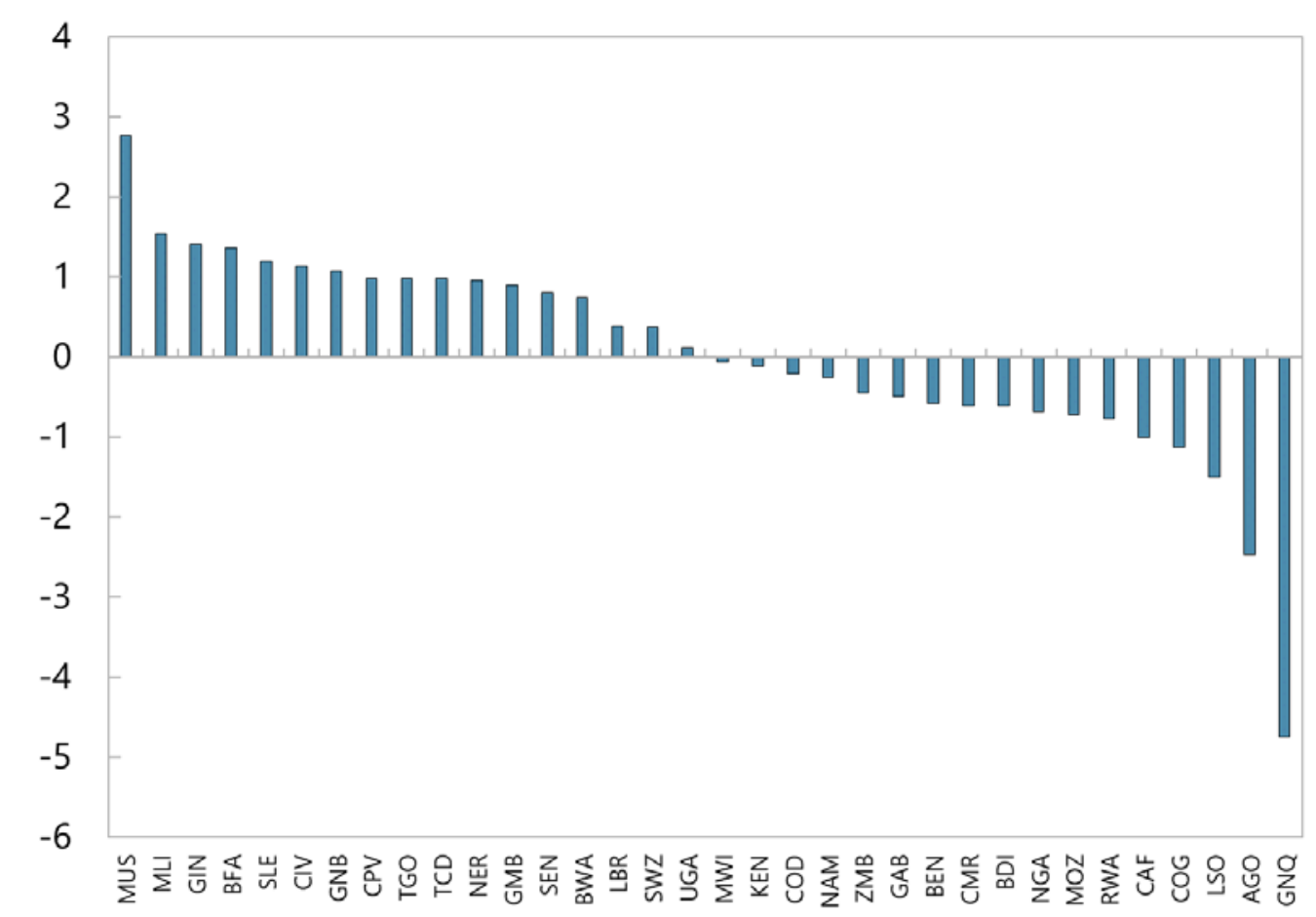

Source: Authors' estimates.

\section{SumMARY AND CONCLUSIONS}

Cross-border banking in Africa has changed significantly in recent years. The retrenchment of European groups has opened the market to other banking groups especially from SSA, but also from other regions, such as North Africa (Morocco), the Middle East (Qatar), and Asia (China and India). Banks headquartered in SSA have emerged with a significant footprint in the region by expanding primarily through subsidiaries. From 2000 to 2015, pan-African banking groups have invested about $\$ 6$ billion in cross-border subsidiaries, including syndicated and bilateral loans for infrastructure financing. This expansion appears to have cooled down in recent years. Since 2013 new investment has declined significantly, and even turned negative in 2015, when a decline in net equity due to losses was not offset by new injections of capital.

While the investment strategies differ significantly across banking groups, the data analyzed in this study highlight some common trends. Most notably, investment appears to be statistically associated with factors that can be related to transaction costs, such as geographic and cultural proximity. Investment was significantly larger between countries sharing a common language or border and declined with the geographic distance between the source and destination country. 
Furthermore, the econometric evidence derived in this study is consistent with the hypothesis that investment flows may have been driven partly by a search for yield and partly by a diversification motive.

- Group profitability and home country growth appear with a significant negative coefficient, suggesting that groups may have resorted to cross-border investment in order to boost dissatisfactory returns or saturation in the domestic market.

- $\quad$ Consistent with a search-for-yield motive, this study identified some patterns that could stem from risk avoidance: (i) inflation in the host country had significant negative coefficient, (ii) inflation and trade openness in the host country have a significant positive coefficient, and (iii) the exchange rate volatility against the U.S. dollar also have a significant negative coefficient (especially, in the home country), which could be interpreted as a sign that banking groups were more reluctant to expand across borders when exchange rate risk made the associated gains more uncertain.

- $\quad$ The possible presence of a diversification motive is suggested by the positive coefficient of bilateral exchange rate volatility on cross-border investment, which appears however only in some regressions. Among the banking groups, empirical support for the search for yield motive appears stronger in the smaller groups (i.e., other than Ecobank and Standard/Stanbic), which may not be surprising, considering that different groups pursue different investment strategies. Ecobank's cross-border investment does not appear to be strongly correlated with the group's profitability, while Standard/Stanbic's cross-border investment tends to be higher in periods when returns on equity and inflation in South Africa are high, suggesting that such investments might have been used as a channel to reinvest profits.

It should be noted that the empirical methods used in this study do not permit to identify the direction of causality, and the estimates obtained explain only a small share of the variance of the dependent variable, and many factors that could have played a significant role have not been included in the regressions. Further research is needed to investigate more deeply the drivers of cross-border investment in bank subsidiaries in sub-Saharan Africa. For instance, to what extend do these flows respond to bilateral trade, nonbank FDI, or remittance flows between the host and recipient countries? Are investments higher, or lower, in countries that export natural resources? Are they affected by commodity prices or other economic indicators, such as world growth or global interest rates? What has been the impact of the regulatory and institutional environment in the host and in the originating country? And why did investment flows slow down after 2013? Additional empirical analysis along these lines might provide useful insights into the economics of sub-Saharan Africa's growing banking sector. Also, it is important to consider bilateral trade as another potential driver of crossborder banking flows - past research has identified a positive relationship between bilateral trade and cross-border exposures (Blank and Buch, 2010 and Cerruti, Hale, and Minoiu, 2015, among others). 
Table 1. Panel Regression Results

\begin{tabular}{|c|c|c|c|}
\hline & (1) & (2) & (3) \\
\hline VARIABLES $^{1}$ & $\mathrm{RE}$ & GLS & GMM \\
\hline In GDP (host) (contemporary) & $\begin{array}{c}0.896 * * * \\
(0.261)\end{array}$ & $\begin{array}{c}0.620^{* * *} \\
(0.224)\end{array}$ & $\begin{array}{c}0.771 * * \\
(0.385)\end{array}$ \\
\hline In GDP (home) (contemporary) & $\begin{array}{c}1.578^{* * * *} \\
(0.549)\end{array}$ & $\begin{array}{c}1.651^{* * *} \\
(0.406)\end{array}$ & $\begin{array}{c}1.679 * * * \\
(0.563)\end{array}$ \\
\hline In distance & $\begin{array}{c}-0.715^{* * *} \\
(0.169)\end{array}$ & $\begin{array}{c}-0.817^{* * *} \\
(0.190)\end{array}$ & $\begin{array}{c}-0.763 * * * \\
(0.160)\end{array}$ \\
\hline language dummy & $\begin{array}{l}1.207^{*} \\
(0.689)\end{array}$ & $\begin{array}{c}1.032 * \\
(0.547)\end{array}$ & $\begin{array}{c}0.855 \\
(0.767)\end{array}$ \\
\hline border dummy & $\begin{array}{l}1.538^{* *} \\
(0.762)\end{array}$ & $\begin{array}{c}2.445^{* * *} \\
(0.701)\end{array}$ & $\begin{array}{c}1.709 * * \\
(0.750)\end{array}$ \\
\hline In equity (group) & $\begin{array}{c}0.008 \\
(0.351)\end{array}$ & $\begin{array}{c}0.013 \\
(0.225)\end{array}$ & $\begin{array}{c}-0.201 \\
(0.357)\end{array}$ \\
\hline ROE (group) & $\begin{array}{c}-0.057^{* * *} \\
(0.016)\end{array}$ & $\begin{array}{c}-0.047^{* * *} \\
(0.016)\end{array}$ & $\begin{array}{c}-0.065 * * * \\
(0.017)\end{array}$ \\
\hline real GDP growth (host) & $\begin{array}{l}-0.037 \\
(0.039)\end{array}$ & $\begin{array}{c}-0.043 \\
(0.037)\end{array}$ & $\begin{array}{l}-0.040 \\
(0.047)\end{array}$ \\
\hline inflation (host) & $\begin{array}{c}0.000 \\
(0.003)\end{array}$ & $\begin{array}{l}-0.002 \\
(0.003)\end{array}$ & $\begin{array}{l}-0.001 \\
(0.004)\end{array}$ \\
\hline inflation (squared) (host) & $\begin{array}{l}-0.000 \\
(0.000)\end{array}$ & $\begin{array}{c}0.000 \\
(0.000)\end{array}$ & $\begin{array}{c}0.000 \\
(0.000)\end{array}$ \\
\hline trade openness (host) & $\begin{array}{c}0.015 \\
(0.010)\end{array}$ & $\begin{array}{c}0.010 \\
(0.006)\end{array}$ & $\begin{array}{c}0.004 \\
(0.012)\end{array}$ \\
\hline exchange rate volatility (host) & $\begin{array}{l}-0.590 \\
(0.460)\end{array}$ & $\begin{array}{l}-0.535^{*} \\
(0.304)\end{array}$ & $\begin{array}{c}-0.780 \\
(0.541)\end{array}$ \\
\hline real GDP growth (home) & $\begin{array}{l}-0.007 \\
(0.031)\end{array}$ & $\begin{array}{c}-0.001 \\
(0.034)\end{array}$ & $\begin{array}{l}-0.004 \\
(0.032)\end{array}$ \\
\hline inflation (home) & $\begin{array}{c}0.433^{* *} \\
(0.205)\end{array}$ & $\begin{array}{c}0.338^{* *} \\
(0.161)\end{array}$ & $\begin{array}{c}0.238 \\
(0.211)\end{array}$ \\
\hline inflation (squared) (home) & $\begin{array}{l}-0.014 \\
(0.009)\end{array}$ & $\begin{array}{l}-0.011^{*} \\
(0.006)\end{array}$ & $\begin{array}{l}-0.008 \\
(0.009)\end{array}$ \\
\hline trade openness (home) & $\begin{array}{c}0.083^{* * * *} \\
(0.025)\end{array}$ & $\begin{array}{c}0.082^{* * *} \\
(0.020)\end{array}$ & $\begin{array}{c}0.071 * * * \\
(0.026)\end{array}$ \\
\hline exchange rate volatility (home) & $\begin{array}{c}-0.972 * \\
(0.522)\end{array}$ & $\begin{array}{c}-1.404 * * * \\
(0.399)\end{array}$ & $\begin{array}{l}-0.713 \\
(0.550)\end{array}$ \\
\hline In investment (lagged) & & & $\begin{array}{l}-0.010 \\
(0.015)\end{array}$ \\
\hline Constant & $\begin{array}{c}-78.641^{* * *} \\
(13.424)\end{array}$ & $\begin{array}{c}-75.387^{* * *} \\
(10.160)\end{array}$ & $\begin{array}{c}-73.409 * * * \\
(15.145)\end{array}$ \\
\hline Observations & 1,190 & 1,190 & 1,121 \\
\hline Number of banks & 100 & 100 & 96 \\
\hline F-test P-Value & 0.000 & & \\
\hline r2 & . & . & . \\
\hline r2_w & 0.114 & . & . \\
\hline r2_b & 0.106 & . & . \\
\hline r2_o & 0.108 & . & . \\
\hline Hansen P-value & & & 1.000 \\
\hline \multicolumn{4}{|c|}{ Robust standard errors in parentheses } \\
\hline
\end{tabular}

Source: Authors' calculations. 


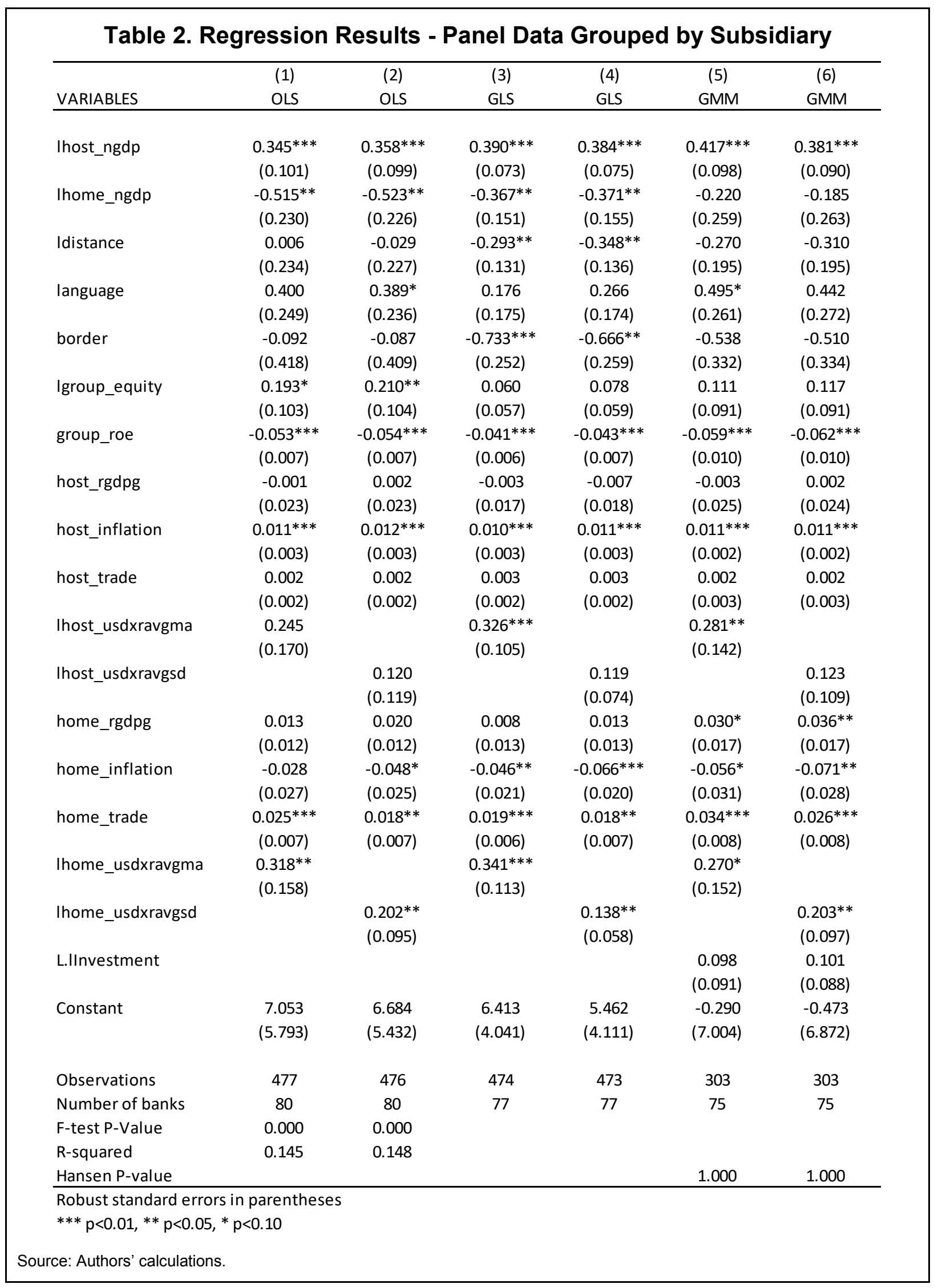




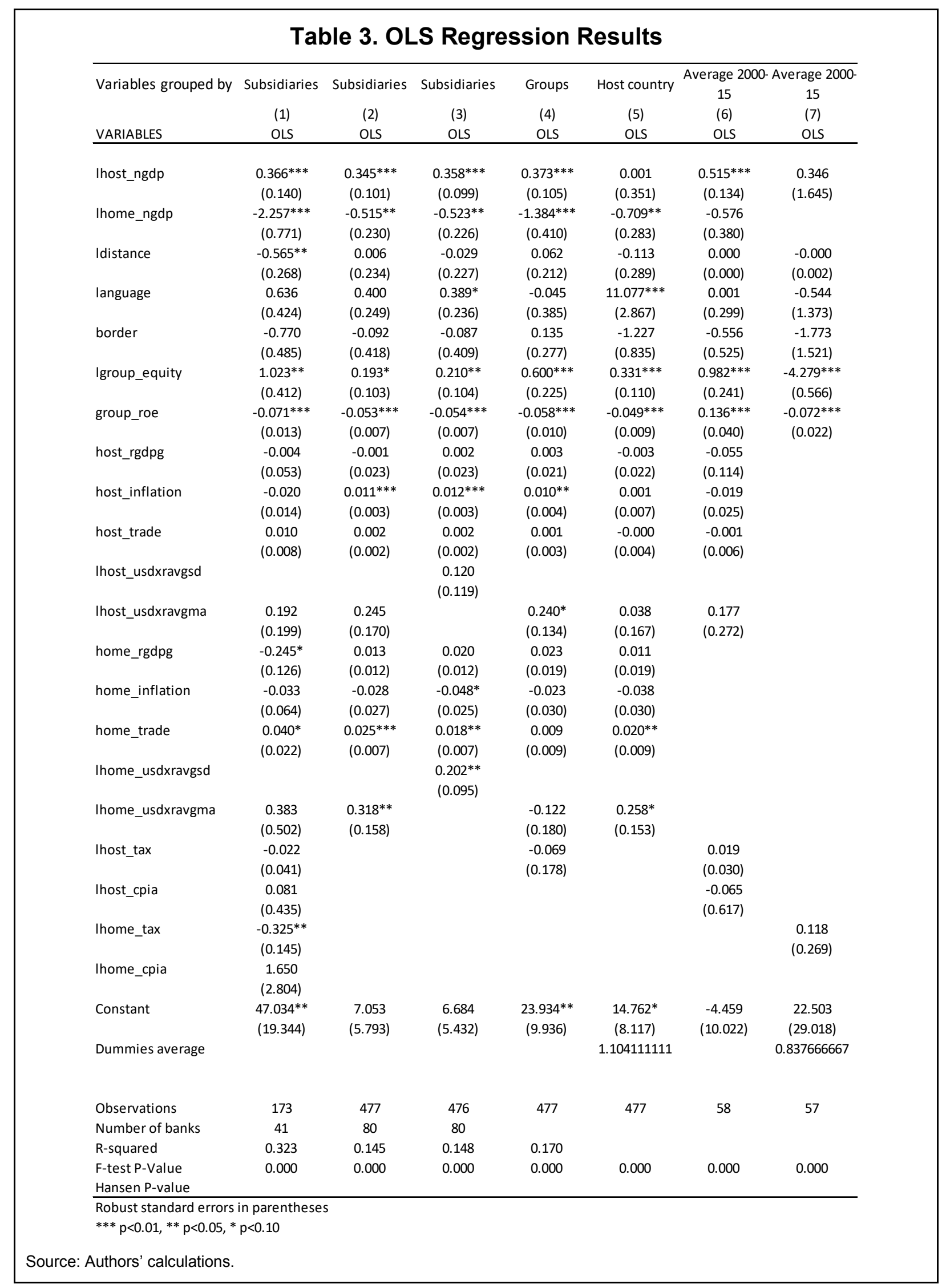

\section{CInternational Monetary Fund. Not for Redistribution}




\begin{tabular}{|c|c|c|c|c|c|c|}
\hline \multicolumn{7}{|c|}{ Table 4. Panel Regression Results-Selected Groups (RE) } \\
\hline VARIABLES & all groups & Ecobank & $\begin{array}{c}\text { Standard/ } \\
\text { Stanbic }\end{array}$ & $\begin{array}{l}\text { Other } \\
\text { groups }\end{array}$ & $\begin{array}{c}\text { All groups } \\
\text { except } \\
\text { Ecobank }\end{array}$ & $\begin{array}{c}\text { All groups } \\
\text { except } \\
\text { Standard/ } \\
\text { Stanbic } \\
\end{array}$ \\
\hline In GDP (host) (contemporary) & $\begin{array}{c}1.027^{* * *} \\
(0.270)\end{array}$ & $\begin{array}{l}0.759 \\
(0.534)\end{array}$ & $\begin{array}{c}-1.558 * * * \\
(0.497)\end{array}$ & $\begin{array}{l}0.714^{*} \\
(0.419)\end{array}$ & $\begin{array}{c}0.924 * * * \\
(0.335)\end{array}$ & $\begin{array}{c}0.900 * * * \\
(0.320)\end{array}$ \\
\hline In GDP (home) (contemporary) & $\begin{array}{c}1.640^{* * *} \\
(0.551)\end{array}$ & $\begin{array}{c}5.305^{* * *} \\
(1.466)\end{array}$ & $\begin{array}{c}8.781 * * * \\
(1.692)\end{array}$ & $\begin{array}{l}-0.259 \\
(0.637)\end{array}$ & $\begin{array}{c}1.841^{* * *} \\
(0.679)\end{array}$ & $\begin{array}{c}0.309 \\
(0.526)\end{array}$ \\
\hline In distance & $\begin{array}{c}-0.686 * * * \\
(0.186)\end{array}$ & $\begin{array}{c}-0.759 * * * \\
(0.227)\end{array}$ & $\begin{array}{c}2.645^{* * *} \\
(0.878)\end{array}$ & $\begin{array}{c}-0.683 * * * \\
(0.181)\end{array}$ & $\begin{array}{c}-0.637^{* * *} \\
(0.203)\end{array}$ & $\begin{array}{c}-0.755^{* * *} \\
(0.147)\end{array}$ \\
\hline language dummy & $\begin{array}{c}0.431 \\
(0.921)\end{array}$ & $\begin{array}{c}0.977 \\
(1.391)\end{array}$ & $\begin{array}{l}-3.024 \\
(2.121)\end{array}$ & $\begin{array}{c}0.226 \\
(0.748)\end{array}$ & $\begin{array}{c}0.868 \\
(0.839)\end{array}$ & $\begin{array}{l}-0.062 \\
(0.939)\end{array}$ \\
\hline border dummy & $\begin{array}{c}0.711 \\
(0.799)\end{array}$ & $\begin{array}{c}2.760 * * \\
(1.088)\end{array}$ & $\begin{array}{l}-0.185 \\
(2.289)\end{array}$ & $\begin{array}{c}1.062 \\
(0.909)\end{array}$ & $\begin{array}{c}0.439 \\
(0.919)\end{array}$ & $\begin{array}{c}1.121 \\
(0.833)\end{array}$ \\
\hline In equity (group) & $\begin{array}{l}-0.042 \\
(0.347)\end{array}$ & $\begin{array}{l}-1.573 \\
(1.048)\end{array}$ & $\begin{array}{c}-1.268^{* * *} \\
(0.261)\end{array}$ & $\begin{array}{c}1.343^{* * *} \\
(0.417)\end{array}$ & $\begin{array}{l}-0.342 \\
(0.384)\end{array}$ & $\begin{array}{c}1.186^{* * *} \\
(0.379)\end{array}$ \\
\hline ROE (group) & $\begin{array}{c}-0.058^{* * *} \\
(0.016)\end{array}$ & $\begin{array}{l}-0.004 \\
(0.036)\end{array}$ & $\begin{array}{c}0.229 \\
(0.204)\end{array}$ & $\begin{array}{c}-0.050 * * \\
(0.020)\end{array}$ & $\begin{array}{c}-0.049 * * * \\
(0.019)\end{array}$ & $\begin{array}{c}-0.060 * * * \\
(0.017)\end{array}$ \\
\hline real GDP growth (host) & $\begin{array}{l}-0.017 \\
(0.043)\end{array}$ & $\begin{array}{l}-0.021 \\
(0.058)\end{array}$ & $\begin{array}{l}-0.087 \\
(0.142)\end{array}$ & $\begin{array}{l}-0.013 \\
(0.070)\end{array}$ & $\begin{array}{c}-0.004 \\
(0.066)\end{array}$ & $\begin{array}{l}-0.020 \\
(0.045)\end{array}$ \\
\hline inflation (host) & $\begin{array}{c}0.028 \\
(0.026)\end{array}$ & $\begin{array}{c}0.072 \\
(0.064)\end{array}$ & $\begin{array}{l}-0.008 \\
(0.048)\end{array}$ & $\begin{array}{c}0.011 \\
(0.040)\end{array}$ & $\begin{array}{c}0.030 \\
(0.027)\end{array}$ & $\begin{array}{c}0.024 \\
(0.037)\end{array}$ \\
\hline inflation (squared) (host) & $\begin{array}{l}-0.000 \\
(0.000)\end{array}$ & $\begin{array}{l}-0.000 \\
(0.000)\end{array}$ & $\begin{array}{c}0.000 \\
(0.000)\end{array}$ & $\begin{array}{l}-0.000 \\
(0.000)\end{array}$ & $\begin{array}{l}-0.000 \\
(0.000)\end{array}$ & $\begin{array}{l}-0.000 \\
(0.000)\end{array}$ \\
\hline trade openness (host) & $\begin{array}{c}0.013 \\
(0.011)\end{array}$ & $\begin{array}{c}0.024 \\
(0.017)\end{array}$ & $\begin{array}{c}0.024 \\
(0.024)\end{array}$ & $\begin{array}{c}0.009 \\
(0.013)\end{array}$ & $\begin{array}{c}0.008 \\
(0.013)\end{array}$ & $\begin{array}{c}0.014 \\
(0.011)\end{array}$ \\
\hline real GDP growth (home) & $\begin{array}{l}-0.006 \\
(0.032)\end{array}$ & $\begin{array}{l}-0.053 \\
(0.044)\end{array}$ & $\begin{array}{l}-0.334 \\
(0.685)\end{array}$ & $\begin{array}{l}-0.004 \\
(0.079)\end{array}$ & $\begin{array}{l}-0.059 \\
(0.076)\end{array}$ & $\begin{array}{c}0.019 \\
(0.032)\end{array}$ \\
\hline inflation (home) & $\begin{array}{c}0.504 * * \\
(0.206)\end{array}$ & $\begin{array}{c}1.894^{* * *} \\
(0.483)\end{array}$ & $\begin{array}{l}-0.084 \\
(0.807)\end{array}$ & $\begin{array}{c}0.625^{* *} \\
(0.280)\end{array}$ & $\begin{array}{c}0.321 \\
(0.235)\end{array}$ & $\begin{array}{c}0.716^{* * *} \\
(0.249)\end{array}$ \\
\hline inflation (squared) (home) & $\begin{array}{c}-0.015^{*} \\
(0.009)\end{array}$ & $\begin{array}{c}-0.069 * * * \\
(0.019)\end{array}$ & $\begin{array}{c}0.098^{* *} \\
(0.044)\end{array}$ & $\begin{array}{l}-0.017 \\
(0.012)\end{array}$ & $\begin{array}{l}-0.010 \\
(0.011)\end{array}$ & $\begin{array}{c}-0.021^{* *} \\
(0.011)\end{array}$ \\
\hline trade openness (home) & $\begin{array}{c}0.072 * * * \\
(0.024)\end{array}$ & $\begin{array}{c}0.078 * * \\
(0.032)\end{array}$ & $\begin{array}{l}-0.201 \\
(0.175)\end{array}$ & $\begin{array}{l}0.065^{*} \\
(0.036)\end{array}$ & $\begin{array}{c}0.097^{* * *} \\
(0.035)\end{array}$ & $\begin{array}{c}0.071 * * * \\
(0.026)\end{array}$ \\
\hline exchange rate volatility (bilateral) & $\begin{array}{l}-1.040 \\
(1.579)\end{array}$ & $\begin{array}{c}2.611 \\
(2.134)\end{array}$ & $\begin{array}{l}-2.907 \\
(2.300)\end{array}$ & $\begin{array}{l}-1.584 \\
(2.288)\end{array}$ & $\begin{array}{l}-2.663 \\
(2.006)\end{array}$ & $\begin{array}{c}-0.030 \\
(1.712)\end{array}$ \\
\hline exchange rate volatility (bilateral; squared) & $\begin{array}{l}-0.138 \\
(0.485)\end{array}$ & $\begin{array}{l}-1.251^{*} \\
(0.677)\end{array}$ & $\begin{array}{c}0.261 \\
(0.589)\end{array}$ & $\begin{array}{l}-0.011 \\
(0.725)\end{array}$ & $\begin{array}{c}0.466 \\
(0.598)\end{array}$ & $\begin{array}{l}-0.523 \\
(0.600)\end{array}$ \\
\hline Constant & $\begin{array}{c}-75.302 * * * \\
(13.244)\end{array}$ & $\begin{array}{c}-166.186^{* * *} \\
(32.901)\end{array}$ & $\begin{array}{c}-203.896^{* * *} \\
(39.985)\end{array}$ & $\begin{array}{l}-29.399 * \\
(17.417)\end{array}$ & $\begin{array}{c}-76.853^{* * *} \\
(15.882)\end{array}$ & $\begin{array}{c}-47.231^{* * *} \\
(14.150)\end{array}$ \\
\hline Observations & 1,172 & 437 & 204 & 531 & 735 & 968 \\
\hline Number of banks & 97 & 30 & 15 & 52 & 67 & 82 \\
\hline F-test P-Value & 0.00 & 0.00 & 0.00 & 0.00 & 0.00 & 0.00 \\
\hline r2_w & 0.12 & 0.18 & 0.14 & 0.13 & 0.09 & 0.14 \\
\hline r2_b & 0.09 & 0.31 & 0.73 & 0.16 & 0.09 & 0.14 \\
\hline r2_o & 0.10 & 0.21 & 0.24 & 0.13 & 0.09 & 0.14 \\
\hline $\begin{array}{l}\text { Robust standard errors in parentheses } \\
* * * p<0.01,{ }^{* *} p<0.05,{ }^{*} p<0.10\end{array}$ & & & & & & \\
\hline Source: Authors' calculations. & & & & & & \\
\hline
\end{tabular}




\begin{tabular}{|c|c|c|c|c|}
\hline \multicolumn{5}{|c|}{ Table 5. Cross Subsidiary Results-Baseline Model } \\
\hline \multicolumn{5}{|l|}{ VARIABLES $^{1}$} \\
\hline \multirow{2}{*}{ In GDP (host) (contemporary) } & $1.675^{* *}$ & $1.741^{* *}$ & $1.662^{* * *}$ & $1.674^{* *}$ \\
\hline & $(0.822)$ & $(0.867)$ & $(0.819)$ & $(0.808)$ \\
\hline \multirow[t]{2}{*}{ In GDP (home) (contemporary) } & 0.211 & 0.221 & 0.229 & 0.178 \\
\hline & $(0.288)$ & $(0.313)$ & $(0.286)$ & $(0.279)$ \\
\hline \multirow[t]{2}{*}{ In distance } & $-0.636^{* * *}$ & $-0.835^{* * *}$ & $-0.624^{* * *}$ & $-0.634 * * *$ \\
\hline & $(0.196)$ & $(0.258)$ & $(0.194)$ & $(0.189)$ \\
\hline \multirow[t]{2}{*}{ border dummy } & 1.207 & 1.238 & 1.343 & $1.202^{*}$ \\
\hline & $(0.878)$ & $(0.957)$ & $(0.854)$ & $(0.678)$ \\
\hline \multirow{2}{*}{ language dummy } & 1.228 & 1.167 & 1.060 & 1.170 \\
\hline & $(0.829)$ & $(0.937)$ & $(0.792)$ & $(0.756)$ \\
\hline \multirow[t]{2}{*}{ In equity (group) } & $-2.928^{* * *}$ & - & $-2.878^{* * *}$ & $-2.843^{* * *}$ \\
\hline & $(0.997)$ & & $(0.992)$ & $(0.975)$ \\
\hline In assets (group) & - & $\begin{array}{c}-1.946^{* * *} \\
(0.576)\end{array}$ & - & - \\
\hline \multirow[t]{2}{*}{ ROE (group) } & $-0.211^{* * *}$ & $-0.174^{* *}$ & $-0.209^{* * *}$ & $-0.199^{* *}$ \\
\hline & $(0.079)$ & $(0.080)$ & $(0.079)$ & $(0.077)$ \\
\hline \multirow[t]{2}{*}{ real GDP growth (host) } & -1.455 & -1.353 & $-1.501^{*}$ & $-1.696^{*}$ \\
\hline & $(0.893)$ & $(0.954)$ & $(0.888)$ & $(0.866)$ \\
\hline \multirow[t]{2}{*}{ inflation (host) } & 0.005 & -0.003 & -0.033 & -0.000 \\
\hline & $(0.069)$ & $(0.073)$ & $(0.043)$ & $(0.001)$ \\
\hline \multirow[t]{2}{*}{ trade openness (host) } & 0.001 & -0.001 & 0.000 & -0.001 \\
\hline & $(0.010)$ & $(0.011)$ & $(0.010)$ & $(0.010)$ \\
\hline \multirow[t]{2}{*}{ inflation (home) } & $-0.879^{* * *}$ & $-0.581^{* * *}$ & $-0.859^{* * *}$ & $-0.815^{* *}$ \\
\hline & $(0.322)$ & $(0.212)$ & $(0.320)$ & $(0.311)$ \\
\hline \multirow[t]{2}{*}{ trade openness (home) } & $-0.300^{* *}$ & - & $-0.304^{* *}$ & $-0.290^{* *}$ \\
\hline & $(0.143)$ & & $(0.143)$ & $(0.141)$ \\
\hline \multirow[t]{2}{*}{ exchange rate volatility (bilateral) } & 1.583 & 1.549 & 0.483 & - \\
\hline & $(2.076)$ & $(2.453)$ & $(1.376)$ & \\
\hline \multirow[t]{2}{*}{ exchange rate volatility (bilateral; squ } & -0.826 & -0.728 & - & - \\
\hline & $(1.165)$ & $(1.295)$ & & \\
\hline \multirow[t]{2}{*}{ Constant } & -2.699 & -25.745 & -2.594 & -2.947 \\
\hline & $(29.791)$ & $(23.333)$ & $(29.701)$ & $(29.442)$ \\
\hline Observations & 97 & 86 & 97 & 100 \\
\hline R-squared & 0.390 & 0.394 & 0.386 & 0.378 \\
\hline F-test P-Value & 0.000 & 0.000 & 0.000 & 0.000 \\
\hline r2_w & & & & \\
\hline \multicolumn{5}{|l|}{ Standard errors in parentheses } \\
\hline \multicolumn{5}{|l|}{$* * * p<0.01, * * p<0.05, * p<0.10$} \\
\hline \multicolumn{5}{|l|}{${ }^{1}$ Averages for the period $2000-15$. } \\
\hline urce: Authors' calculations. & & & & \\
\hline
\end{tabular}

(CInternational Monetary Fund. Not for Redistribution 


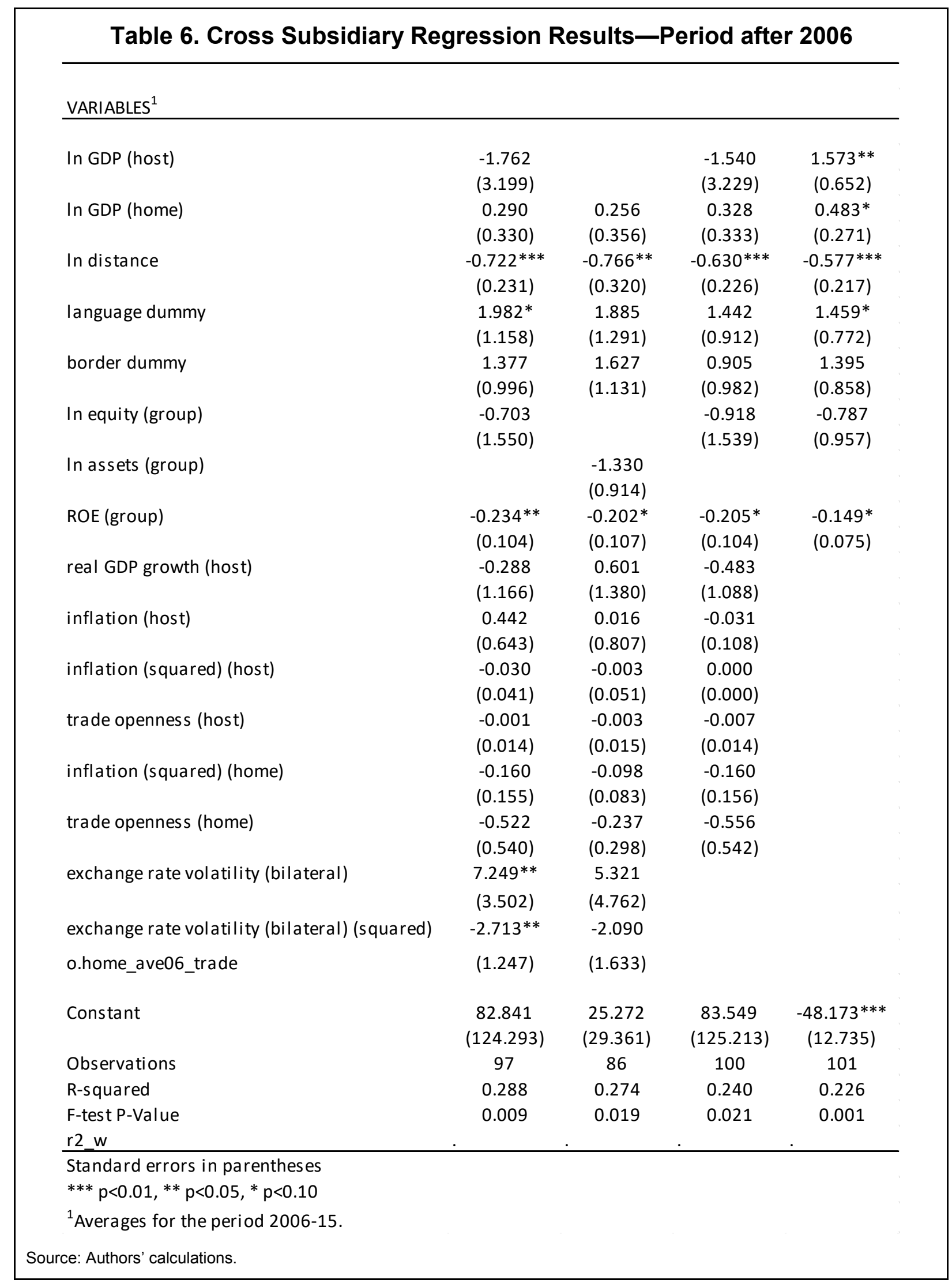

CInternational Monetary Fund. Not for Redistribution 


\begin{tabular}{|c|c|c|c|c|}
\hline VARIABLES $^{1}$ & All groups & Ecobank & $\begin{array}{c}\text { Standard/ } \\
\text { Stanbic }\end{array}$ & $\begin{array}{l}\text { Other } \\
\text { groups }\end{array}$ \\
\hline \multirow[t]{2}{*}{ In GDP (host) (contemporary) } & $1.675^{* *}$ & - & - & -26.694 \\
\hline & $(0.822)$ & & & $(20.565)$ \\
\hline \multirow[t]{2}{*}{ In GDP (home) (contemporary) } & 0.211 & 0.496 & -0.565 & 0.042 \\
\hline & $(0.288)$ & $(0.542)$ & $(1.095)$ & $(0.364)$ \\
\hline \multirow[t]{2}{*}{ In distance } & $-0.636 * * *$ & $-0.835^{* *}$ & 1.796 & -0.360 \\
\hline & $(0.196)$ & $(0.330)$ & $(1.973)$ & $(0.223)$ \\
\hline \multirow[t]{2}{*}{ border dummy } & 1.207 & 1.952 & 2.007 & $2.111^{* *}$ \\
\hline & $(0.878)$ & $(1.716)$ & $(3.723)$ & $(0.838)$ \\
\hline \multirow[t]{2}{*}{ la ngua ge dummy } & 1.228 & 1.233 & 4.333 & 0.495 \\
\hline & $(0.829)$ & $(1.291)$ & $(2.443)$ & $(0.915)$ \\
\hline \multirow[t]{2}{*}{ In equity (group) } & $-2.928 * * *$ & - & - & 80.876 \\
\hline & $(0.997)$ & & & (60.939) \\
\hline \multirow[t]{2}{*}{ ROE (group) } & $-0.211 * * *$ & - & - & 3.240 \\
\hline & $(0.079)$ & & & $(2.432)$ \\
\hline \multirow[t]{2}{*}{ real GDP growth (host) } & -1.455 & $-3.826 * *$ & 2.534 & -0.258 \\
\hline & $(0.893)$ & $(1.696)$ & $(3.694)$ & $(1.042)$ \\
\hline \multirow[t]{2}{*}{ inflation (host) } & 0.005 & -0.000 & -0.001 & 0.008 \\
\hline & (0.069) & $(0.002)$ & $(0.002)$ & $(0.032)$ \\
\hline \multirow[t]{2}{*}{ trade openness (host) } & 0.001 & 0.007 & 0.006 & 0.013 \\
\hline & $(0.010)$ & $(0.019)$ & $(0.035)$ & $(0.013)$ \\
\hline \multirow[t]{2}{*}{ inflation (home) } & $-0.879 * * *$ & - & - & 27.018 \\
\hline & $(0.322)$ & & & $(20.353)$ \\
\hline \multirow[t]{2}{*}{ trade openness (home) } & $-0.300 * *$ & - & - & 7.994 \\
\hline & $(0.143)$ & & & $(5.999)$ \\
\hline \multirow[t]{2}{*}{ exchange rate volatility (bilateral) } & 1.583 & - & - & - \\
\hline & $(2.076)$ & & & \\
\hline exchange rate volatility (bilateral; $\varsigma$ & -0.826 & - & - & - \\
\hline \multirow[t]{2}{*}{ Constant } & $\begin{array}{l}(1.165) \\
-2.699\end{array}$ & -8.009 & -15.318 & -649.515 \\
\hline & $(29.791)$ & $(13.364)$ & $(24.191)$ & $(472.039)$ \\
\hline Observations & 97 & 32 & 16 & 52 \\
\hline R-squared & 0.390 & 0.445 & 0.388 & 0.449 \\
\hline F-test P-Value & 0.000 & 0.030 & 0.659 & 0.011 \\
\hline \multicolumn{5}{|l|}{ r2_w } \\
\hline \multicolumn{5}{|l|}{ Standard errors in parentheses } \\
\hline \multicolumn{5}{|l|}{$* * * p<0.01, * * p<0.05, * p<0.10$} \\
\hline \multicolumn{5}{|l|}{${ }^{1}$ Averages for the period $2000-15$. } \\
\hline surce: Authors' calculations. & & & & \\
\hline
\end{tabular}

(CInternational Monetary Fund. Not for Redistribution 


\section{Annex I. Dependent Variables}

Two different dependent variables are used in these regressions: the value of the group's ownership share in the subsidiary ("ownership"), which is a stock variable measuring the value of the shares of the subsidiary that are owned by any company of the group (the holding company as well as any other company controlled by the group) at the end of each year, and the net investment in the subsidiary ("investment"), which is a flow variable measuring the amount of resources invested in the capital of the subsidiary by any other company belonging to the group in a given year.

Ownership is computed as the product of the group's percentage share of the subsidiary's capital (defined as the sum of the ownership shares held by any company belonging to the group, irrespective of the value of the group's ownership in each of these entities) multiplied by the subsidiary's net equity (as reported in the financial statements or in proprietary databases). Depending on data availability, the group's ownership shares are taken from the Orbis online database or from the groups' or subsidiaries' annual reports, occasionally interpolating for missing data, and the value of the net equity of the subsidiaries are provided by Fitch (using preferably consolidated data) or taken from the annual reports (Tables A1 and A2).

Investment is a net flow of resources from the group to the subsidiary, which takes the form of subscription or purchase of shares, sale of shares (in which case investment is negative), and retained earnings. The group's share of the subsidiary's retained earnings (after tax profits not distributed as dividends) is treated as investment because the group's control over the subsidiary enables it, in principle, to withdraw all its profits through a dividend distribution; the group's decision not to take advantage of this opportunity is thus tantamount to a decision to re-invest in the subsidiary (part of) its share of its profits ("passive investment"). The same does not hold in the case of losses: whereas a subsidiary's profit give the group a legal entitlement to a dividend distribution (whether it exerts it or not), losses do not entail a legal obligation to replenish the subsidiary's capital, and hence cannot be considered as (passive) disinvestment; indeed, if the subsidiary's shareholders decided to inject new capital to cover its losses, this operation would be treated as net new investment.

In summary, the investment variable has been computed as the sum of: (a) the value of the shares bought or sold by the group during the year, measured as the average value of the subsidiaries' shares at the beginning and at the end of the year; and (b) the change in the value of the shares held by the group at the beginning of the year resulting from the change in the total net equity of the subsidiary, if this change is positive (i.e., consisting essentially of retained earnings). In computing all these values, adjustment is made for any valuation changes arising from movements in bilateral exchange rates.

Hence, equity and investment are closely, but not perfectly, related. The amount invested (disinvested) in the subsidiary in a given year increases (reduces) the total value of the equity owned by the group, but the latter is affected also by other factors, such as losses (which 
reduce net equity but are not a form of disinvestment) and changes in exchange rates (which alter the value of the net equity of the subsidiary when measured in the group's reference currency).

\begin{tabular}{|llll|}
\hline \multicolumn{4}{c|}{ Table A1. Data Sources, by Variable and by Group } \\
\hline Group & $\begin{array}{l}\text { Ownership Share in } \\
\text { the Subsidiaries (S) }\end{array}$ & $\begin{array}{l}\text { Net Equity of the } \\
\text { Subsidiaries (E) }\end{array}$ & $\begin{array}{l}\text { Ownership Value } \\
\text { (V = S*E) }\end{array}$ \\
\hline Ecobank & Orbis; Annual Reports & Fitch; Annual Reports & computed \\
First Rand & Orbis; Annual Reports & Fitch & computed \\
Guaranty Trust & Orbis & Fitch & computed \\
KCB & Orbis & Fitch & computed \\
Nedbank & Orbis & Fitch & computed \\
Orabank & Annual Reports; Orbis & Annual Reports & computed \\
Stanbic & Orbis & Fitch & computed \\
Standard Bank & Orbis & Annual Reports; Fitch & computed \\
UBA & Annual Reports; Orbis; & Annual Reports & Annual Reports \\
& data collected from the & & \\
\hline cource: Authors' calculations. & & \\
\hline
\end{tabular}




\section{Table A2. Data Definitions and Sources}

\begin{tabular}{|c|c|c|c|}
\hline Indicator & Variable & Definition & Source \\
\hline share & Group share in subsidiary & $\begin{array}{l}\text { The data on the banking group's ownership share in each of its } \\
\text { subsidiaries is defined as the ratio of the nominal value of the } \\
\text { shares held by all entities controlled by the group to the total } \\
\text { nominal value of the shares issued by the subsidiary, } \\
\text { irrespective of the value of the group's ownership in the entities } \\
\text { that own these shares. }\end{array}$ & $\begin{array}{l}\text { Bureau van Dijk Orbis } \\
\text { database; Published } \\
\text { financial statements }\end{array}$ \\
\hline equity & Subsidiary net equity & The net equity of the bank subsidiaries in U.S. dollars. & $\begin{array}{l}\text { Fitch Connect database; } \\
\text { Published financial } \\
\text { statements }\end{array}$ \\
\hline ownership & $\begin{array}{l}\text { Group ownership in } \\
\text { subsidiary }\end{array}$ & $\begin{array}{l}\text { The data on the banking group's ownership in a subsidiary is } \\
\text { calculated as the product of its ownership share in the } \\
\text { subsidiary by the value of the subsidiary's net equity. }\end{array}$ & IMF staff calculations \\
\hline investment & $\begin{array}{l}\text { Group investment in } \\
\text { subsidiary }\end{array}$ & $\begin{array}{l}\text { The data on the banking group's net investment in a bank } \\
\text { subsidiary is defined as the sum of the group's net purchases of } \\
\text { ownership shares in the subsidiary and any increase in the value } \\
\text { of the group's ownership in that subsidiary associated with the } \\
\text { increase in the net equity of that subsidiary due to the exchange } \\
\text { rates movements. But if the value of the group's ownership } \\
\text { decreased due to the exchange rates movements during the } \\
\text { year, the change in value will not be considered. }\end{array}$ & IMF staff calculations \\
\hline group_asset & Group total asset & The banking group's total asset in U.S. dollars. & Fitch Connect database \\
\hline $\begin{array}{l}\text { group_equit } \\
y\end{array}$ & Group total equity & The banking group's total equity in U.S. dollars. & Fitch Connect database \\
\hline group_roa & Group ROA & The banking group's return on assets. & Fitch Connect database \\
\hline group_roe & Group ROE & The banking group's return on equity. & Fitch Connect database \\
\hline ngdp & $\begin{array}{l}\text { Nominal GDP in U.S. } \\
\text { dollars }\end{array}$ & $\begin{array}{l}\text { GDP at purchaser's prices is the sum of gross value added by all } \\
\text { resident producers in the economy plus any product taxes and } \\
\text { minus any subsidies not included in the value of the products. } \\
\text { Data are in current U.S. dollars. }\end{array}$ & $\begin{array}{l}\text { World Bank World } \\
\text { Development Indicators } \\
\text { database }\end{array}$ \\
\hline inflation & $\begin{array}{l}\text { Inflation (consumer } \\
\text { prices index annual } \\
\text { percent change) }\end{array}$ & $\begin{array}{l}\text { Inflation as measured by the consumer price index reflects the } \\
\text { annual percentage change in the cost to the average consumer } \\
\text { of acquiring a basket of goods and services that may be fixed or } \\
\text { changed at specified intervals, such as yearly. The Laspeyres } \\
\text { formula is generally used. }\end{array}$ & $\begin{array}{l}\text { World Bank World } \\
\text { Development Indicators } \\
\text { database }\end{array}$ \\
\hline cpi & $\begin{array}{l}\text { Consumer prices index } \\
(2010=100)\end{array}$ & $\begin{array}{l}\text { Consumer price index reflects changes in the cost to the average } \\
\text { consumer of acquiring a basket of goods and services that may } \\
\text { be fixed or changed at specified intervals, such as yearly. The } \\
\text { Laspeyres formula is generally used. Data are period averages. }\end{array}$ & $\begin{array}{l}\text { World Bank World } \\
\text { Development Indicators } \\
\text { database }\end{array}$ \\
\hline $\operatorname{tax}$ & $\begin{array}{l}\text { Tax revenue as percent } \\
\text { of GDP }\end{array}$ & $\begin{array}{l}\text { Tax revenue refers to compulsory transfers to the central } \\
\text { government for public purposes. Certain compulsory transfers } \\
\text { such as fines, penalties, and most social security contributions } \\
\text { are excluded. Refunds and corrections of erroneously collected } \\
\text { tax revenue are treated as negative revenue. }\end{array}$ & $\begin{array}{l}\text { World Bank World } \\
\text { Development Indicators } \\
\text { database }\end{array}$ \\
\hline
\end{tabular}




\begin{tabular}{|c|c|c|c|}
\hline \multicolumn{4}{|c|}{ Table A2. Data Definitions and Sources (Continued) } \\
\hline Indicator & Variable & Definition & Source \\
\hline trade & Trade as percent of GDP & $\begin{array}{l}\text { Trade is the sum of exports and imports of goods and services } \\
\text { measured as a share of gross domestic product. }\end{array}$ & $\begin{array}{l}\text { World Bank World } \\
\text { Development Indicators } \\
\text { database }\end{array}$ \\
\hline institution & Rule of law & $\begin{array}{l}\text { Rule of Law captures perceptions of the extent to which agents } \\
\text { have confidence in and abide by the rules of society, and in } \\
\text { particular the quality of contract enforcement, property rights, } \\
\text { the police, and the courts, as well as the likelihood of crime and } \\
\text { violence. Estimate gives the country's score on the aggregate } \\
\text { indicator, in units of a standard normal distribution, i.e. ranging } \\
\text { from approximately }-2.5 \text { to } 2.5 \text {. }\end{array}$ & $\begin{array}{l}\text { World Bank Worldwide } \\
\text { Governance Indicators } \\
\text { database }\end{array}$ \\
\hline usdxravg & $\begin{array}{l}\text { U.S. dollar exchange rate } \\
\text { (avg) }\end{array}$ & $\begin{array}{l}\text { The annual average domestic currency per U.S. dollars exchange } \\
\text { rates. }\end{array}$ & $\begin{array}{l}\text { IMF International } \\
\text { Financial Statistics } \\
\text { database }\end{array}$ \\
\hline usdxreop & $\begin{array}{l}\text { U.S. dollar exchange rate } \\
\text { (eop) }\end{array}$ & $\begin{array}{l}\text { The end of period domestic currency per U.S. dollars exchange } \\
\text { rates. }\end{array}$ & $\begin{array}{l}\text { IMF International } \\
\text { Financial Statistics } \\
\text { database }\end{array}$ \\
\hline bi_nxr & $\begin{array}{l}\text { Nominal bilateral } \\
\text { exchange rate }\end{array}$ & $\begin{array}{l}\text { Calculated as the annual average host country currency per } \\
\text { home country currency exchange rates. }\end{array}$ & $\begin{array}{l}\text { IMF International } \\
\text { Financial Statistics } \\
\text { database; IMF staff } \\
\text { calculations }\end{array}$ \\
\hline bi_rxr & $\begin{array}{l}\text { Real bilateral exchange } \\
\text { rate }\end{array}$ & $\begin{array}{l}\text { The real bilateral exchange rate is defined as the ratio of host } \\
\text { country price level to home country price level, where home } \\
\text { country price level is converted into host country currency units } \\
\text { via nominal bilateral exchange rate. The calculation is based on } \\
\text { the two countries' consumer prices index }(2010=100) \text { and } \\
\text { nominal bilateral exchange rate. }\end{array}$ & $\begin{array}{l}\text { World Bank World } \\
\text { Development Indicators } \\
\text { database; IMF } \\
\text { International Financial } \\
\text { Statistics database; IMF } \\
\text { staff calculations }\end{array}$ \\
\hline distance & Capital cities distance & $\begin{array}{l}\text { The distance between capital cities in kilometers calculated } \\
\text { following the great circle formula. }\end{array}$ & CEPII GeoDist database \\
\hline colony & $\begin{array}{l}\text { Common colonial } \\
\text { relationship }\end{array}$ & $\begin{array}{l}\text { The dummy variable that identifies whether the home countries } \\
\text { and the host countries share common colonial relationship or } \\
\text { not. If equals to } 1 \text {, then there is a common colonial relationship. }\end{array}$ & CEPII GeoDist database \\
\hline language & Common language & $\begin{array}{l}\text { The dummy variable that identifies whether the home countries } \\
\text { and the host countries share common language or not. The } \\
\text { language is restricted to the use of English, Frence or } \\
\text { Portuguese as official languages. If equals } 1 \text {, then there is a } \\
\text { common language. }\end{array}$ & CIA World Factbook \\
\hline border & Common border & $\begin{array}{l}\text { The dummy variable that identifies whether the home countries } \\
\text { and the host countries share common land border or not. If } \\
\text { equals to } 1 \text {, then there is a common land border. }\end{array}$ & CIA World Factbook \\
\hline
\end{tabular}




\section{Annex II. Micro-Foundations of the Gravity Model Applied to Cross-Border Banking}

A theoretical micro-foundation of the application of the gravity model of trade to cross-border banking is provided by Martin and Rey (2004). In their formalization, each country i $(0 \leq i \leq N)$ is populated by risk averse agents endowed with a given amount of tradable goods (the numeraire) and a risky project. In the first period, agents consume part of their endowment and trade with other agents. Agents in country $i$ pay $p_{j}=\left(1+\tau_{i j}\right)$ for a share $\tau_{i j}$ of a project run in country $j$. In the second period each project in country $j$ pays dividends $d_{j}$ in only one of $L$ possible states of nature, and 0 in all other states. The number of states of nature is larger than the number of traded assets and then the total number of projects; hence, markets are incomplete. The maximization problem of a representative agent is given by:

$$
\left.\left.\left\{\begin{array}{l}
\max \\
c_{1} h_{i}\left(\begin{array}{c}
h_{i} \\
k_{j}
\end{array}\right)_{1 \leq j \leq N, 1 \leq k_{j} \leq n_{j}}
\end{array}\right\} c_{1, h_{i}+\beta E\left(\frac{c_{2, h_{i}}^{1-\frac{1}{\sigma}}}{1-\frac{1}{\sigma}}\right)}\right\}\right\}
$$

subject to

$$
c_{1, h_{i}}+\sum_{j=1}^{N} \sum_{k_{j}=1}^{n_{j}} p_{j}\left(1+\tau_{i j}\right) x_{k_{j}}^{h_{i}}=y_{i}+p_{i}
$$

where $\sigma$ represents the elasticity of substitution between assets

Agent $h_{i}$ 's demand for shares in projects in country $j$ is given by:

$$
\left(\begin{array}{c}
h_{i} \\
x_{j}
\end{array}\right)=\kappa \frac{\left(d_{j}\right)^{\sigma-1}}{\left[p_{j}\left(1+\tau_{i j}\right)\right]^{\sigma}}
$$

Aviat and Coeurdacier (2007) solved this maximization problem in terms of aggregate asset holdings of country $i$ from country $j$ (Asset i $_{i j}$ ):

$$
\operatorname{Asset}_{i j}=n_{i}\left(p_{j} n_{j} x_{j}^{h_{i}}\right)=\kappa \frac{n_{i} n_{j}}{\left(1+\tau_{i j}\right)^{\sigma}}\left(\frac{d_{j}}{p_{j}}\right)^{\sigma-1}
$$


Assuming gross returns on assets in country $j$ are given by $R_{j}=\frac{d_{j}}{p_{j}}$, this yields the gravity equation, formulated in logarithmic terms as:

$$
\log \left(\text { Asset }_{i j}\right)=\alpha+\log \left(n_{i} n_{j}\right)-\sigma \log \left(1+\tau_{i j}\right)+(\sigma-1) \log \left(R_{j}\right)
$$

Where $\alpha=\log (\kappa)$ is a constant, the second term on the right-hand side reflects the combined market sizes of both countries, the third term captures the effect of trading costs in financial markets (which includes any distance-related transaction costs), and the third term-not strictly belonging to the "gravity" component of the model — can be interpreted as a "return chasing" component (Aviat and Coeurdacier, 2007), equivalent to the "search for yield" discussed in this study. 


\section{Annex III. Network Connectivity}

The countries with the largest (direct and indirect) ownership network connections are Nigeria, South Africa, Morocco, and Kenya. ${ }^{31}$ When foreign ownership linkages are excluded, South Africa and Morocco's estimated connectivity falls - suggesting that these countries' network are driven more by foreign ownership interests than those of Nigeria and Kenya.

\section{Network Connectivity}

Standard Banks Subs by Type

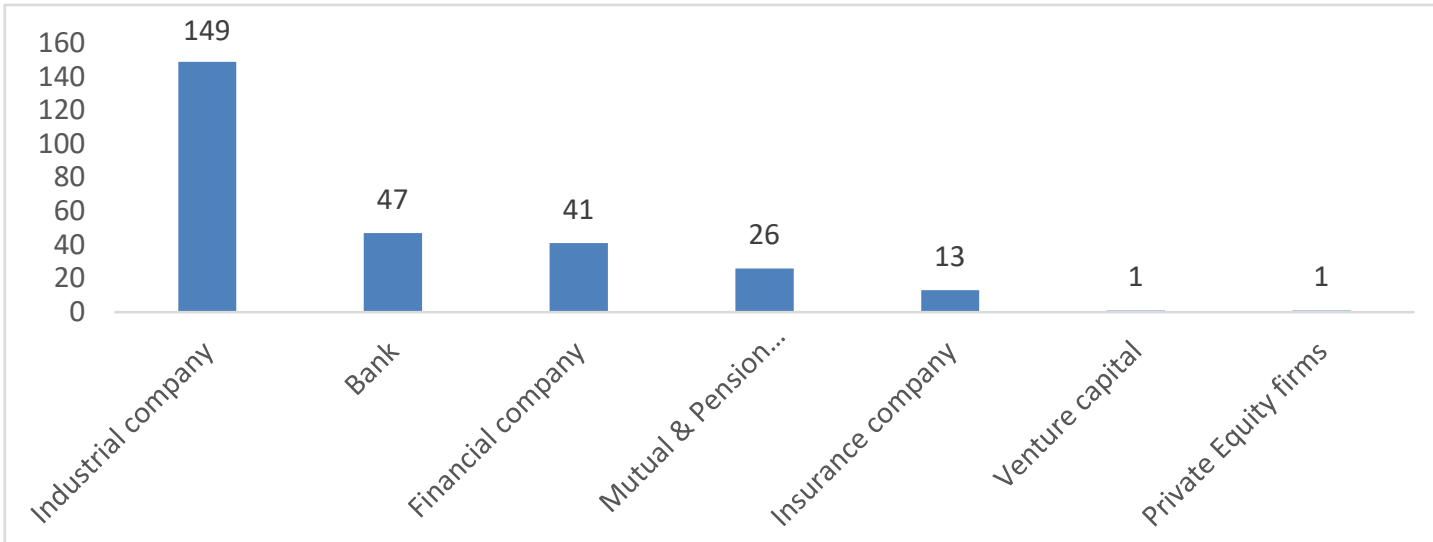

Top 10 Standard Bank Subs by Type and Country

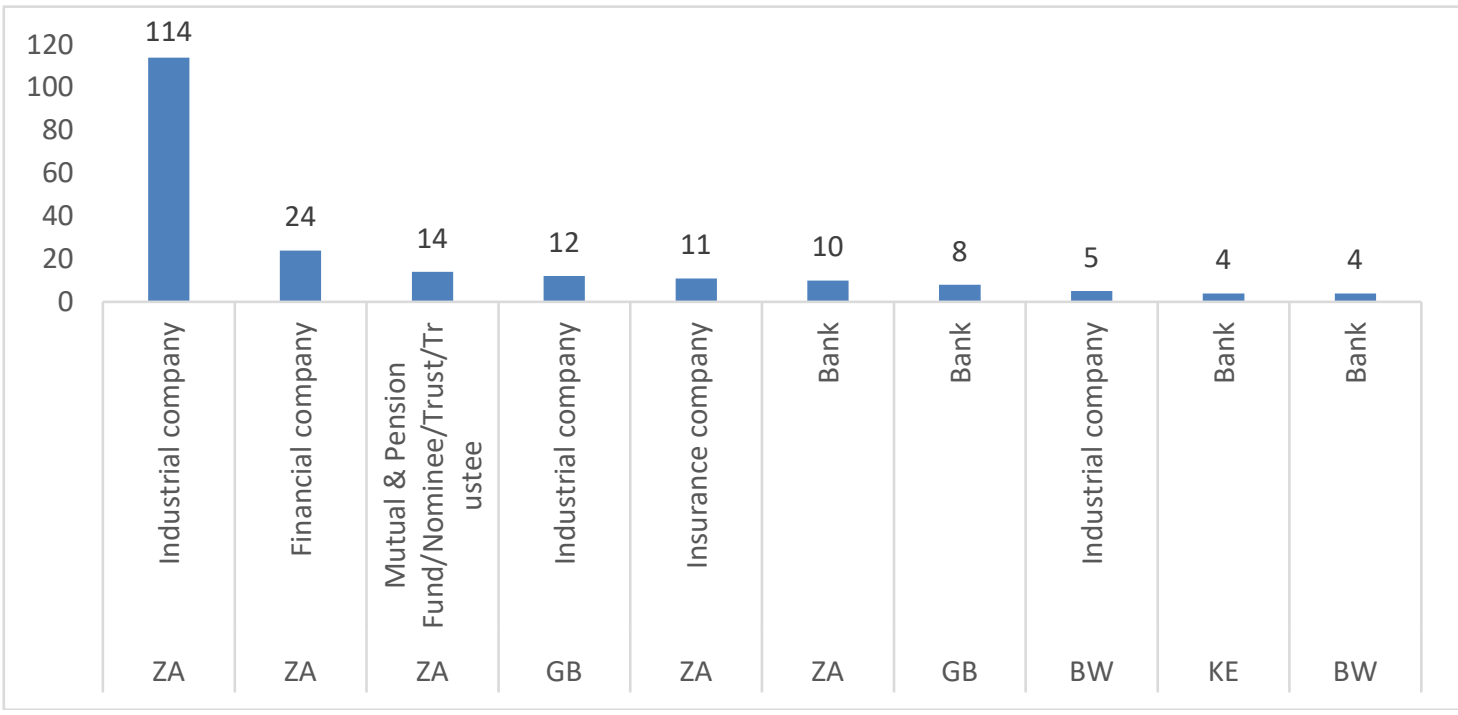

Source: Banks' websites and Annual Reports.

${ }^{31}$ A foreign ownership linkage denotes an equity holding by an African-domiciled parent company in a nonAfrican domiciled subsidiary. All eigenvector centrality scores were computed using both controlling and noncontrolling ownership linkages. 


\section{Network Connectivity}

Network Connectivity: African Banks

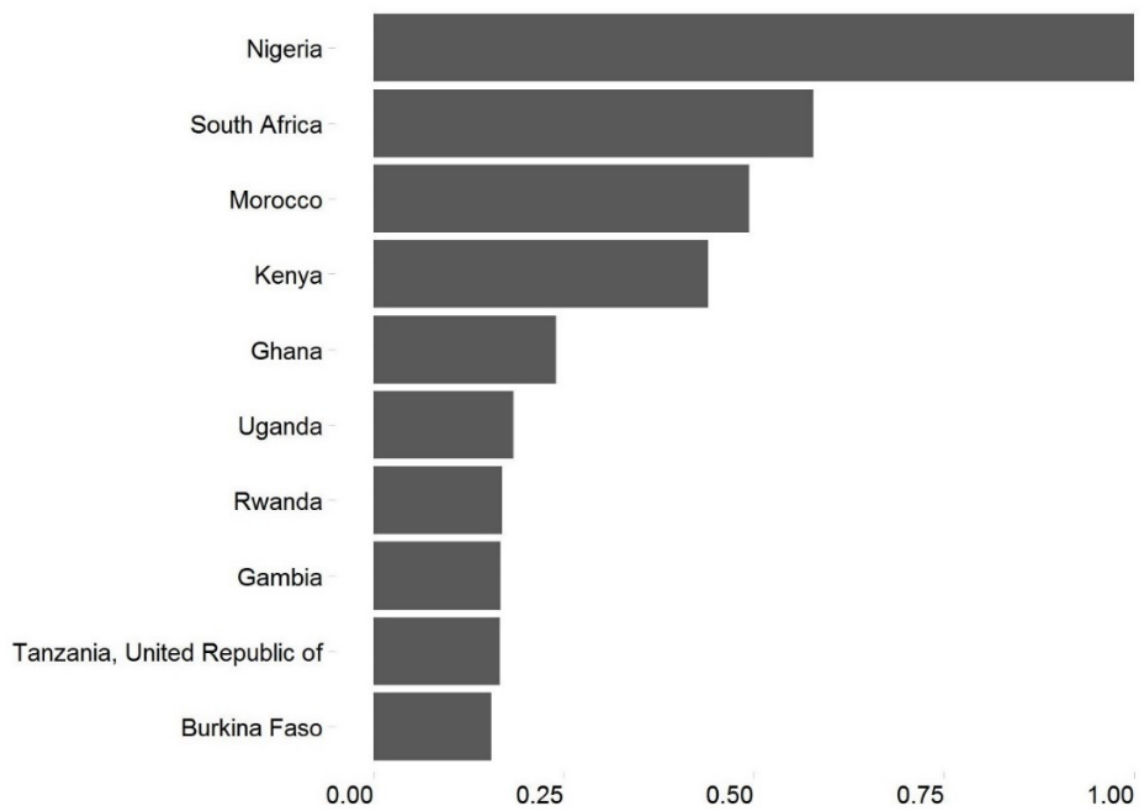

Eigenvector Centrality Score

Network Connectivity: All Sectors

Banking

South Africa

Banking

Morocco

Banking

Kenya

Banking

Ghana

Banking

Cote d'Ivoire

Non-financial Corporate

Uganda

Banking

Tanzania, United Republic of Non-financial Corporate

Zambia

Non-financial Corporate

Rwanda

Banking
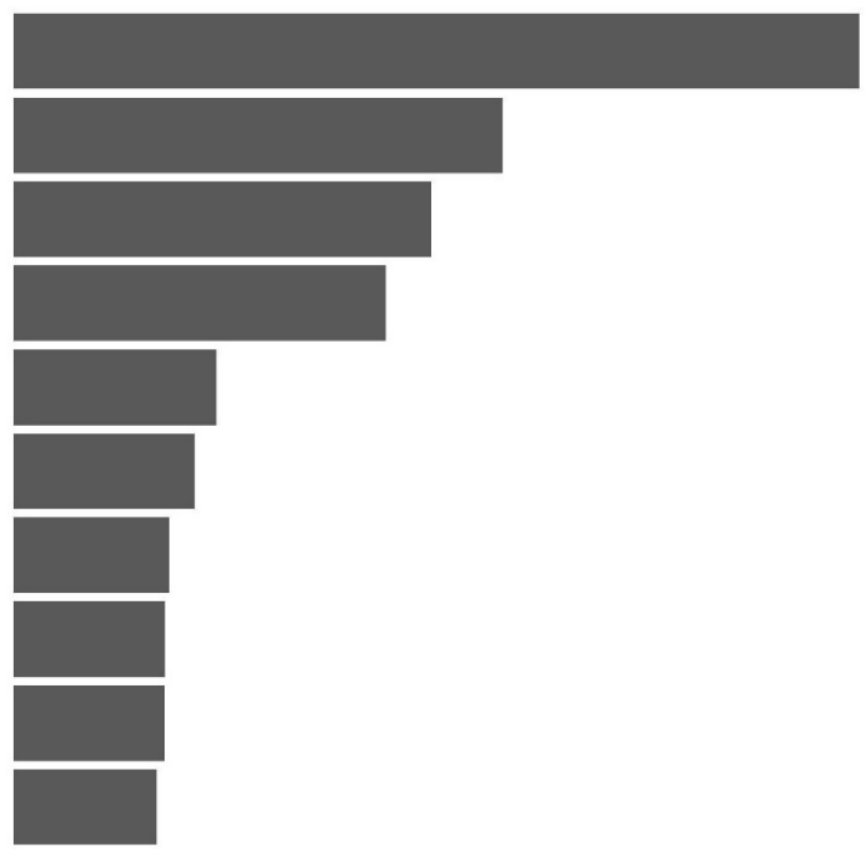

0.00

0.25

0.50

0.75

1.

Source: Orbis and IMF staff calculations.

Eigenvector Centrality Score

CInternational Monetary Fund. Not for Redistribution 


\section{References}

Ananchotikul, N., Piao, S.; and Zoli, E., 2015, "Drivers of Financial IntegrationImplications for Asia," IMF Working Paper WP/15/160, International Monetary Fund, pp. 40.

Arena, Marco; Reinhart, Carmen; and Vazquez, Francisco, 2007, "The Lending Channel in Emerging Economies: Are Foreign Banks Different?" IMF Working Paper WP/07/48, Washington: International Monetary Fund.

Aviat A.; Coeurdacier, N., 2007, The Geography of Trade in Goods and Asset Holdings, Journal of International Economics 71, pp. 22-51.

Baltagi, Badi.H. (2001) Econometric Analysis of Panel Data, New York, John Wiley and Sons, pp. 293.

Blank, S; and Bush, C.M., 2010, "International Bank Portfolios: Short- and Long-Run Responses to Macroeconomic Conditions," Review of International Economics 18(2), pp. 289-306.

Bruno, V.; and Shin, H.S., 2013, "Capital Flows, Cross-Border Banking and Global Liquidity,” NBER Working Paper 19038, pp. 50.

Buch, C.M., 2005, "Distance and International Banking," Review of International Economics 13(4), pp. 787-804.

Cerruti, E.M.; Hale, G; and Minoiu, C., 2015, "Financial Crises and the Composition of Cross-Border Lending," Journal of International Money and Finance 52, pp. 60-81.

Cerruti, E.M.; and Zhou, H.,2018, "Cross-Border Banking and the Circumvention of Macroprudential and Capital Control Measures,” IMF Working Paper WP/18/217, pp. 45.

Christensen, Vibe, 2014, "Financial Integration in Africa: Implications for Monetary Policy and Financial Stability," BIS Papers 76.

Claessens, Stijn, 2016, "Global Banking: Recent Developments and Insights from Research," Review of Finance, pp. 1-43.

Cull, Robert; and Martinez Peria, Maria Soledad, 2013, "Foreign Bank Participation in Developing Countries: What Do We Know about the Drivers and Consequences of this Phenomenon?" in: Encyclopedia of Financial Globalization, edited by Gerard Caprio. Oxford, U.K.: Elsevier.

Enoch C.;Mathieu, P.; and Mecagni, M., 2015, "Pan-African Banking: Opportunities and Challenges for Cross-Border Oversight," African Departmental Paper 15/3, International Monetary Fund, pp. 95. 
Gudmundsdottir, S.; Helagson, O.H.; Leitner, M.; McDonnel, C.; and Schramm, A., 2017, "Gravity in Bank Lending Within the European Union," Barcelona GSE Master Project, pp. 32 .

Herrmann, S.; and Mihaljek, D., 2010, "The Determinants of Cross-Border Bank Flows to Emerging Markets: New Empirical Evidence on the Spread of Financial Crises," BIS Working Paper 315, pp. 38.

Houston, J.F.; Lin, C.; and Ma, Y., 2012, "Regulatory Arbitrage and International Bank Flows," Journal of Finance 67(5), pp. 1845-95.

IMF, 2015, "International Banking After the Crisis: Increasingly Local and Safer?" Global Financial System Report April, Washington, International Monetary Fund, Chapter 2.

Kerl, C. and Niepmann, F., 2015, "What Determines the Composition of International Bank Flows?” IMF Economic Review 63(4), pp. 792-829.

Lane, T.; and Milesi-Ferretti, G.M., 2008, "The Drivers of Financial Globalization," American Economic Review 98(2), pp. 327-32.

Martin, Philippe; and Rey, Helene, 2004, "Financial Super-Markets: Size Matters for Asset Trade," Journal of International Economics 64, pp. 335- 61

Niepmann, F., 2015, “Banking Across Borders," Journal of International Economics 96(2), pp. 244-65.

Portes, R.; and Rey, H., 2005, “The Determinants of Cross-Border Equity Flows,” Journal of International Economics 65 (2), pp. 269-96.

Reinhardt, D.; and Riddiough, S.J., 2015, "The Two Faces of Cross-Border Banking Flows," IMF Economic Review 63(4), pp. 751-91.

Tinbergen, Jan, 1962, “An Analysis of World Trade Flows," in: Tinbergen, Jan (ed.) Shaping the World Economy, New York, NY: Twentieth Century Fund.

World Bank., 2013, "Financial System Stability Assessment: East African Community," Washington. 